A) Check for updates

Cite this: Dalton Trans., 2020, 49 10463

Received 1st June 2020,

Accepted 9th July 2020

DOI: $10.1039 / \mathrm{dOdt01964j}$

rsc.li/dalton

\section{Mono and dinuclear iridium(III) complexes featuring bis-tridentate coordination and Schiff-base bridging ligands: the beneficial effect of a second metal ion on luminescence $\uparrow$}

\author{
Emma V. Puttock, (D) Amit Sil, (D) Dmitry S. Yufit and J. A. Gareth Williams (D) *
}

The synthesis and photophysical properties of a set of iridium(III) complexes featuring tridentate $N^{\wedge} N^{\wedge} O$ coordinating ligands are described, of generic structure $\left[\mid r\left(N^{\wedge} C^{\wedge} N-d p y x\right)\left(N^{\wedge} N \wedge O-L^{n}\right)\right]^{+}(n=1$ to 4$)$ (dpyx = 1,3-dipyridyl-4,6-dimethylbenzene). The proligands $\mathrm{HL}^{n}$ are Schiff bases synthesised by condensation of salicylaldehydes with $\mathrm{N}$-methyl-hydrazinopyridines: they are able to coordinate to the Ir(III) via lateral pyridine- $\mathrm{N}$ and phenolate- $\mathrm{O}^{-}$atoms and a central hydrazone- $\mathrm{N}$ atom; the four examples differ in the substitution pattern within the phenolate ring. The bis-tridentate coordination is confirmed by X-ray diffraction. The complexes are phosphorescent in solution at ambient temperature, with higher quantum yields and longer lifetimes than those of structurally related bis-cyclometallated complexes with an $N^{\wedge} N^{\wedge} \mathrm{C}$-coordinating ligand. Related proligands $\mathrm{H}_{2} \mathrm{~L}^{5}$ and $\mathrm{H}_{2} \mathrm{~L}^{6}$ have been prepared from 4,6-bis(1methyl-hydrazino)pyrimidine. They feature a central pyrimidine and two $\mathrm{N}^{\wedge} \mathrm{N} \wedge \mathrm{O}$ units. They are shown to bind as ditopic, bis-tridentate ligands with two iridium(III) ions, leading to unprecedented dinuclear complexes of the form $\left[\left\{\mid r\left(N^{\wedge} C^{\wedge} N\right)\right\}_{2}\left(O^{\wedge} N^{\wedge} N-N^{\wedge} N^{\wedge} O-L^{n}\right)\right]^{2+}\left(n=5,6 ; N^{\wedge} C^{\wedge} N=\right.$ dpyx or 1,3-dipyridyl-4,6difluoro-benzene), with an intramolecular $|r \cdots| r$ distance of around $6 \AA$ determined crystallographically. Mononuclear analogues $\left[\operatorname{lr}\left(N^{\wedge} C^{\wedge} N-d p y x\right)\left(N^{\wedge} N^{\wedge} O-H L^{n}\right)\right]^{+}$have also been isolated. The dinuclear complexes display a well-defined and unusually intense lowest-energy absorption band in the visible region, around $480 \mathrm{~nm}$. They emit much more efficiently than their mononuclear counterparts, even though the emission wavelengths are comparable. Their superior performance appears to be due to an enhancement in the radiative rate constant, affirming conclusions drawn from recent related studies of dinuclear $\operatorname{Ir}($ III) and $\mathrm{Pt}($ II) complexes with ditopic, pyrimidine-based cyclometallating ligands.

\section{Introduction}

Interest in the light-emitting properties of iridium(III) complexes continues to be intense. Their large-scale use as tripletemitting materials in organic light-emitting diodes (OLEDs) ${ }^{1}$ has been a catalyst for activity in other applications, for example, in light-emitting electrochemical cells (LEECs), ${ }^{2}$ for light-to-chemical/electrical energy conversion, ${ }^{3}$ photocatalysis, ${ }^{4}$ and as emitters in bio-imaging. ${ }^{5}$ Though the bulk of research has focused on mononuclear complexes, it is increas-

Department of Chemistry, Durham University, Durham, DH1 3LE, UK. E-mail:j.a.g.williams@durham.ac.uk

$\dagger$ Electronic supplementary information (ESI) available: Synthetic and characterisation data for $\mathrm{H}_{2} \mathrm{~L}^{7}$ and $\left[\operatorname{Ir}(\right.$ dpyx $\left.) \mathrm{HL}^{7}\right] \mathrm{PF}_{6}$; additional figures showing molecular structures and crystal packing in the crystals; table of key bond lengths and angles determined crystallographically; additional emission spectra. CCDC 2006844-2006849. For ESI and crystallographic data in CIF or other electronic format see DOI: $10.1039 / \mathrm{d} 0 \mathrm{dt} 01964 \mathrm{j}$ ingly recognised that multinuclear complexes have much to offer. $^{6,7}$ In terms of photophysical properties, multinuclear iridium structures tend to fall into one of two categories. In one case, the constituent units retain, to a large extent, properties that are similar to those of the isolated units: the bridging unit plays a relatively minor role other than that of bringing the units together. A "supramolecular" description is appropriate: the absorption profile of the assembly may be quite similar to the summation of the individual components. Examples include several compounds that make use of paraphenylene-bridged bis-bipyridines to link two $\operatorname{Ir}(\mathrm{ppy})_{2}$ units, ${ }^{8,9}$ together with related systems that feature tridentate ligands. ${ }^{10}$ On the other hand, the photophysical properties of the assembly may be fundamentally different from those of related mononuclear complexes: there may be very large effects on the singlet and triplet excited state energies. For example, we have shown how 4,6-diphenylpyrimidine can act as a bis- $N^{\wedge} C$-bridging ligand to form multinuclear complexes that are characterised by much lower absorption and emission energies than 
their mononuclear counterparts. ${ }^{11}$ Moreover, the radiative rate constants of the formally forbidden $\mathrm{T}_{1} \rightarrow \mathrm{S}_{0}$ process are greatly increased through more efficient spin-orbit coupling (SOC), leading to impressive quantum yields, even in the deep red region of the spectrum. Recent review articles collate other examples, ${ }^{6,7}$ and the beneficial effect on SOC extends to related dinuclear complexes of $\mathrm{Pt}(\mathrm{II})^{12,13}$ and to heterometallic assemblies featuring, for example, a combination of $\operatorname{Ir}(\mathrm{III})$ and Pt(II) centres. ${ }^{14}$

Most multinuclear systems comprise metal complex units in which the metal ions are bound to bidentate ligands, e.g., of the form $\operatorname{Ir}\left(\mathrm{L}^{\wedge} \mathrm{L}\right)_{3}$. Since such units are normally racemic mixtures of $\Lambda$ and $\Delta$ isomers, the resulting compounds are necessarily formed as mixtures of diastereoisomers that can be very difficult to separate (e.g., $\Lambda \Lambda / \Delta \Delta+\Lambda \Delta$ in the case of two metal centres). Tridentate ligands may be advantageous in this respect, since metal complexes of meridionally-coordinating tridentate ligands are normally achiral - e.g., complexes of the form $\operatorname{Ir}\left(L^{\wedge} L^{\wedge} L\right)_{2}$ - and hence give only a single product when incorporated into a multinuclear assembly. ${ }^{10,15}$ We have previously made use of $N^{\wedge} C^{\wedge} N$-coordinating ligands based on 1,3dipyridylbenzene (dpyb) to access a diverse range of mononuclear iridium complexes containing one such ligand in conjunction with other bidentate or tridentate ligands, e.g., of the form $\operatorname{Ir}\left(N^{\wedge} C^{\wedge} N\right)\left(C^{\wedge} N^{\wedge} C\right),\left[\operatorname{Ir}\left(N^{\wedge} C^{\wedge} N\right)\left(N^{\wedge} N\right) \mathrm{X}\right]^{+}$, etc. (Fig. 1a, compounds 1, 3-6). ${ }^{16,17}$ Related ligands based on 1,3-bis(benzimidazolyl)benzene have been used in a similar way by Haga and colleagues, readily binding to $\operatorname{Ir}(\mathrm{III})$ in an $N^{\wedge} C^{\wedge} N$ manner. ${ }^{18}$ Chi and co-workers have used the dpyb ligand platform, in conjunction with a second pyrazolyl-based tridentate ligand, to generate brightly emissive complexes (e.g., 2 in Fig. 1a) ${ }^{19}$ and have achieved even more impressive results with related carbene analogues (monoanionic $: C^{\wedge} C^{-\wedge} C$ : coordination, with carbene units in place of the two pyridine rings). ${ }^{20} N^{\wedge} C^{\wedge} N^{-}$ coordinating units have been incorporated into multinuclear assemblies such as 7, 8 and 9 in Fig. 1. Whilst the behaviour of 7 can be rationalised using the supramolecular description (showing energy transfer from the Ir(III) units through to the lowest-energy Ru(II) unit), ${ }^{10 b}$ pyrimidine-bridged systems 8 and 9 and related derivatives display unusually efficient red emission, with luminescence quantum yields approaching unity in some cases. ${ }^{11}$

The work described here had two objectives. The first was to attempt to prepare a new class of dpyb-based iridium(III) complexes, of the form $\left[\operatorname{Ir}\left(N^{\wedge} C^{\wedge} N\right)\left(N^{\wedge} N^{\wedge} O\right)\right]^{+}$, incorporating hydrazone-based $N^{\wedge} N^{\wedge} O$-coordinating ligands. Recently, we showed that proligands based on $N$-methyl- $N$-(2-pyridyl)- $N$ '(salicylidene)hydrazone - readily prepared from low-cost salicylaldehydes and 2-hydrazino-pyridines by simple Schiff-base condensation reactions - can be coordinated to $\mathrm{Pt}(\mathrm{II})$ to generate compounds of the form $\left[\mathrm{Pt}\left(N^{\wedge} N^{\wedge} O\right) \mathrm{Cl}\right]{ }^{21}$ These complexes are phosphorescent in solution under ambient conditions, and emission is further enhanced by metathesis of the monodentate halide to an acetylide, $\left[\operatorname{Pt}\left(N^{\wedge} N^{\wedge} O\right)(\mathrm{C} \equiv \mathrm{C}-\mathrm{Ar})\right]$. It was of interest to examine whether such ligands could be used successfully with iridium(III), in combination with $N^{\wedge} C^{\wedge} N$-coordi- nating ligands, to generate new emissive materials. Secondly, we reasoned that the pyridylhydrazone structure of these ligands would lend itself well to the facile synthesis of ditopic, $O^{\wedge} N^{\wedge} N-N^{\wedge} N^{\wedge} O$-coordinating ligands, through the use of a pyrimidine unit in place of pyridine. ${ }^{22}$ Such ligands should be well set-up for bis-tridentate coordination to two $\operatorname{Ir}\left(N^{\wedge} C^{\wedge} N\right)$ units, by analogy with related cyclometallating pyrimidine and pyrazine-based systems. ${ }^{11,12}$ We report here the synthesis of several mononuclear and binuclear iridium(III) complexes with $N^{\wedge} N^{\wedge} O$ and $O^{\wedge} N^{\wedge} N-N^{\wedge} N^{\wedge} O$-coordinating ligands respectively, together with the crystal structures of representative examples, and an evaluation of their photophysical properties. Interestingly, we find that the dinuclear complexes are much more strongly luminescent than their direct mononuclear counterparts, due to higher radiative rate constants and reinforcing an emerging picture as to the potential influence of a second metal ion on spin-orbit coupling.

\section{Results and discussion}

\section{Proligand design and synthesis}

A number of metal complexes of $N$-(2-pyridyl)- $N$ '-(salicylidene) hydrazone have been reported with $1^{\text {st }}$ row transition metals, e.g. with $\mathrm{Co}^{2+}, \mathrm{Co}^{3+},[\mathrm{V}=\mathrm{O}]^{2+}, \mathrm{Zn}^{2+}$ and $\mathrm{Cd}^{2+} \cdot{ }^{23}$ In our previous work investigating $\mathrm{Pt}$ (II) complexes of this ligand, and derivatives with substituents in the aromatic rings, we found that the resulting $\operatorname{Pt}\left(N^{\wedge} N^{\wedge} O\right) \mathrm{Cl}$ complexes had poor stability, displaying quite rapid light-induced decomposition in solution, compromising the emission properties and rendering them difficult to assess. ${ }^{21}$ The instability was apparently associated with the facile deprotonation of the hydrazone unit. In contrast, complexes of the corresponding $N$-methylated ligands were robust, with no evidence of decomposition. In the present study, we therefore confined our attention to such $N$-methylated ligands. The parent proligand $\mathrm{HL}^{1}$ and three derivatives $\mathrm{HL}^{2-4}$ incorporating substituents in the phenolic ring were prepared from $N$-methyl-hydrazinopyridine and the corresponding salicylaldehyde as shown in Scheme 1a. Meanwhile, the synthesis of the ditopic, $O^{\wedge} N^{\wedge} N-N^{\wedge} N^{\wedge} O$ proligands $\mathrm{H}_{2} \mathrm{~L}^{5-7}$ was achieved by condensation of salicylaldehydes with 4,6-bis(1-methyl-hydrazino)pyrimidine, in turn prepared from 4,6-dichloropyrimidine and $N$-methyl-hydrazine (Scheme 2a). The proligands were obtained as fine white powders in high yield over the two steps, and characterised by ${ }^{1} \mathrm{H}$ and ${ }^{13} \mathrm{C}$ NMR spectroscopy, mass spectrometry and, for $\mathrm{H}_{2} \mathrm{~L}^{5}$ and $\mathrm{H}_{2} \mathrm{~L}^{7}$, by X-ray diffraction.

\section{Complexation to iridium}

It has previously been shown that 1,3-dipyridylbenzene itself binds to iridium(III) primarily through bidentate $N^{\wedge} C^{4}$ as opposed to tridentate $N^{\wedge} C^{2 \wedge} N$ coordination, but the latter binding mode can be attained by incorporating non-hydrogenic substituents at the 4,6-positions of the central ring (e.g., $\left.\mathrm{CH}_{3}, \mathrm{~F}, \mathrm{CF}_{3}\right) \cdot{ }^{16-18}$ In the present instance, we focused on the 


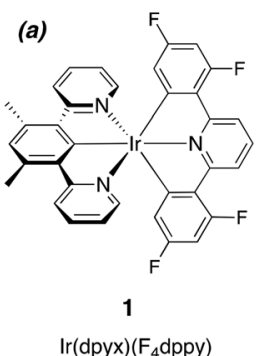

$\operatorname{Ir}(\mathrm{dpyx})\left(\mathrm{F}_{4} \mathrm{dppy}\right)$

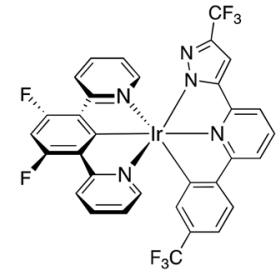

2 $\operatorname{Ir}(\mathrm{dpy})\left(\mathrm{pz}^{\mathrm{CF}} \mathrm{pyph}^{\mathrm{CF} 3}\right)$

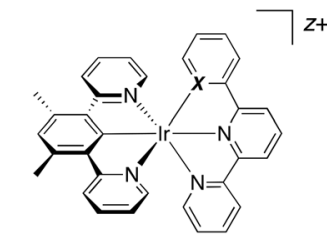

$3[\operatorname{lr}(\text { dpyx })(\text { phbpy })]^{+}(X=C, z=1)$

$4[\operatorname{Ir}(\text { dpyx })(\operatorname{tpy})]^{2+}(X=N, z=2)$

$5 \operatorname{Ir}(\mathrm{dpyx})(\mathrm{ppy}) \mathrm{Cl}(\boldsymbol{X}=\mathrm{C}, \boldsymbol{z}=0)$

$6[\operatorname{lr}(\mathrm{dpyx})(\mathrm{bpy}) \mathrm{Cl}]^{+}(\boldsymbol{X}=\mathrm{N}, \boldsymbol{z}=1)$

(b)

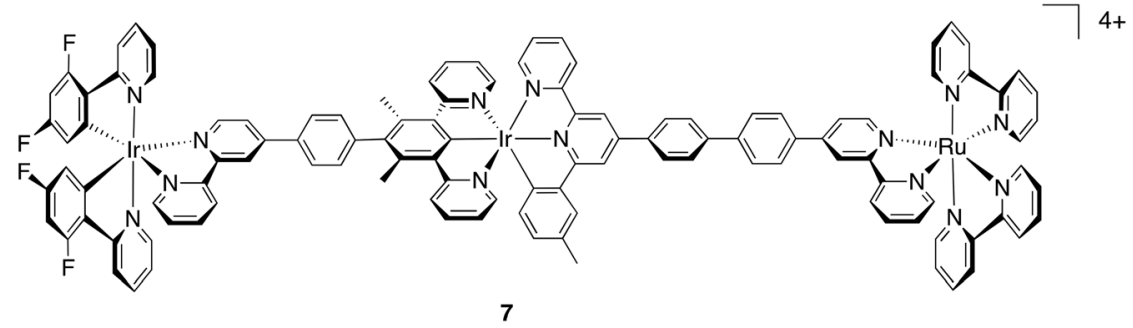

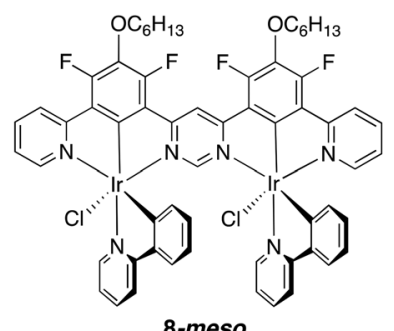

8-meso
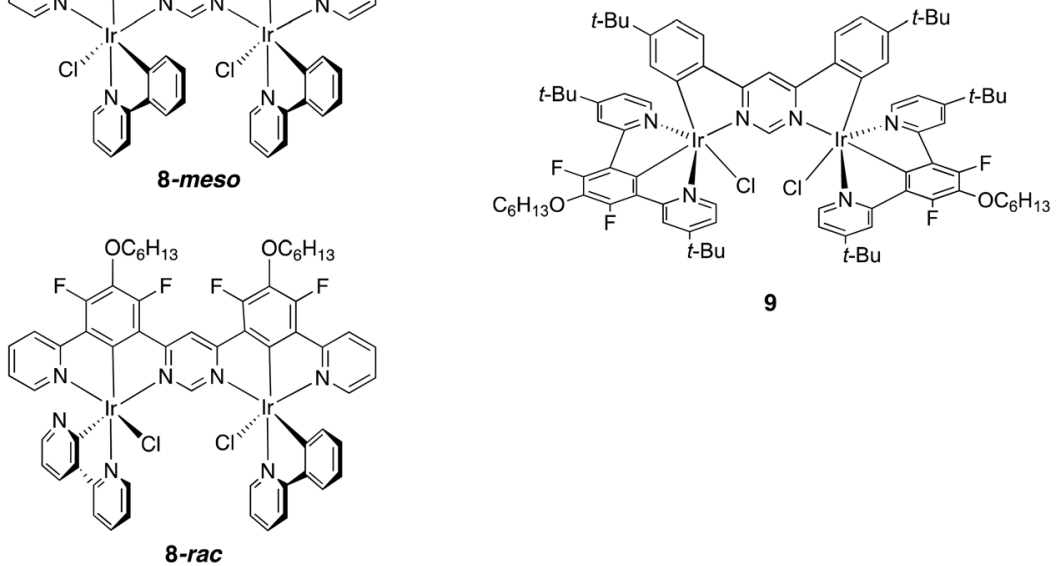

Fig. 1 (a) Representative mononuclear Ir(III) complexes (charge-neutral and cationic) containing $N^{\wedge} C^{\wedge} N$-coordinating 1,3 -dipyridylbenzene derivatives. ${ }^{16-20}$ (b) Examples of multinuclear complexes reported to date that feature $N^{\wedge} C^{\wedge} N$-coordinated Ir(III) centres. Trinuclear complex 7 behaves as a supramolecular system with energy transfer occurring between the constituent units. ${ }^{10 b}$ Dinuclear complexes 8 (which exists as separable meso and rac isomers) and 9 (achiral) are efficient deep-red emitters. ${ }^{11}$

xylene derivative incorporating methyl groups, 1,3-di(pyridyl)4,6-dimethylbenzene (dpyxH), which reacts with hydrated iridium(III) chloride to generate the chloro-bridged dimer $\left[\operatorname{Ir}\left(N^{\wedge} C^{\wedge} N \text {-dpyx }\right) \mathrm{Cl}(\mu-\mathrm{Cl})\right]_{2}$. Reaction of this compound with proligands $\mathrm{HL}^{1-4}$ in ethylene glycol at $190{ }^{\circ} \mathrm{C}$ for 90 min gave the desired mononuclear complexes $\left[\operatorname{Ir}\left(N^{\wedge} C^{\wedge} N\right.\right.$-dpyx $)\left(N^{\wedge} N^{\wedge} O-\right.$ $\left.\left.\mathrm{L}^{1-4}\right)\right]^{+}$as their chloride salts, which were subsequently metathesised to the corresponding hexafluorophosphate salts by precipitation from $\mathrm{KPF}_{6}(\mathrm{aq})$, and purified by recrystallisation from acetonitrile/diethyl ether (Scheme 1b). The identity of the complexes was confirmed by ${ }^{1} \mathrm{H}$ and ${ }^{13} \mathrm{C}$ NMR spectroscopy, mass spectrometry and, for $\left[\operatorname{Ir}(\mathrm{dpyx}) \mathrm{L}^{4}\right] \mathrm{PF}_{6}$, by X-ray diffraction (see below).
The ditopic, bis-tridentate proligands $\mathrm{H}_{2} \mathrm{~L}^{5-6}$ were reacted with $[\operatorname{Ir}(\mathrm{dpyx}) \mathrm{Cl}(\mu-\mathrm{Cl})]_{2}$ under similar conditions (ethylene glycol at $190{ }^{\circ} \mathrm{C}$ for 90 minutes), and the identity of the main products was determined by the stoichiometry used. The use of two equivalents of the proligand relative to the iridium dimer gave the mononuclear complexes $\left[\operatorname{Ir}(\mathrm{dpyx}) \mathrm{HL}^{5-6}\right]^{+}$as the predominant product, whilst a $1: 1$ ratio of materials gave primarily the dinuclear complexes $\left[\{\operatorname{Ir}(\operatorname{dpyx})\}_{2} \mathrm{~L}^{5-6}\right]^{2+}$. In each case, the initially formed chloride salts were metathesised to the hexafluorophosphates, and the products were purified by column chromatography, followed by recrystallisation from acetonitrile/ether. In the case of the bis(t-butyl) derivative $\mathrm{H}_{2} \mathrm{~L}^{7}$, the mononuclear complex $\left[\operatorname{Ir}(\mathrm{dpyx}) \mathrm{HL}^{7}\right]^{+}$was success- 
(a)<smiles>[R7]c1cc([Tl])cc(/C=N/N([Y6])c2ccccn2)c1O</smiles>

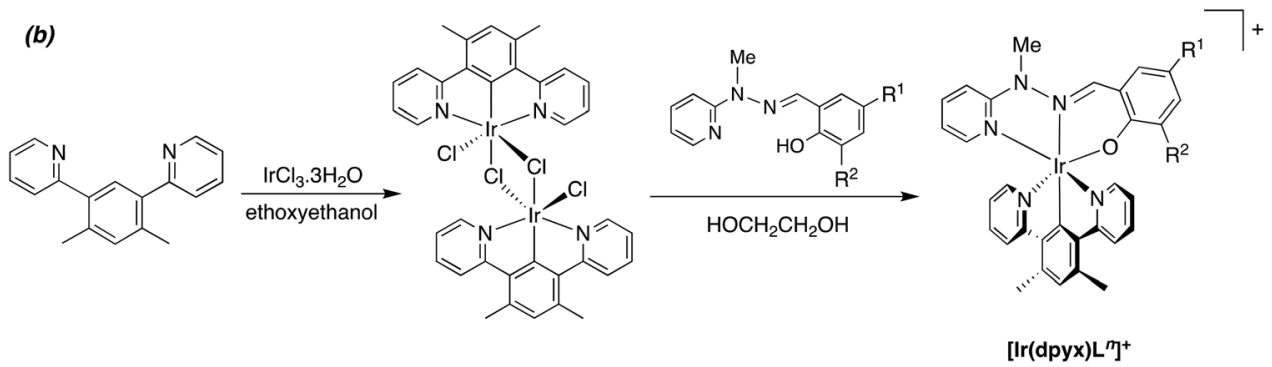

Scheme 1 Synthesis of (a) the $N^{\wedge} N^{\wedge} O$ proligands and (b) their mononuclear iridium(III) complexes described in this work.

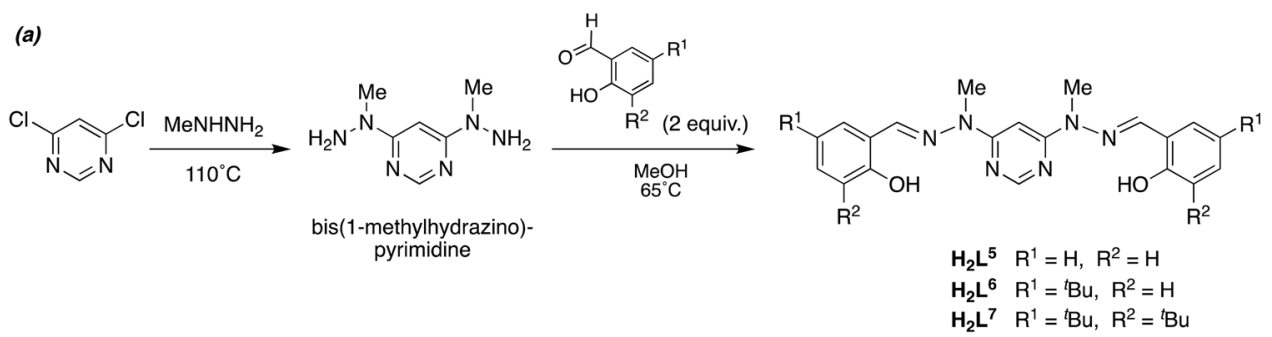

(b)
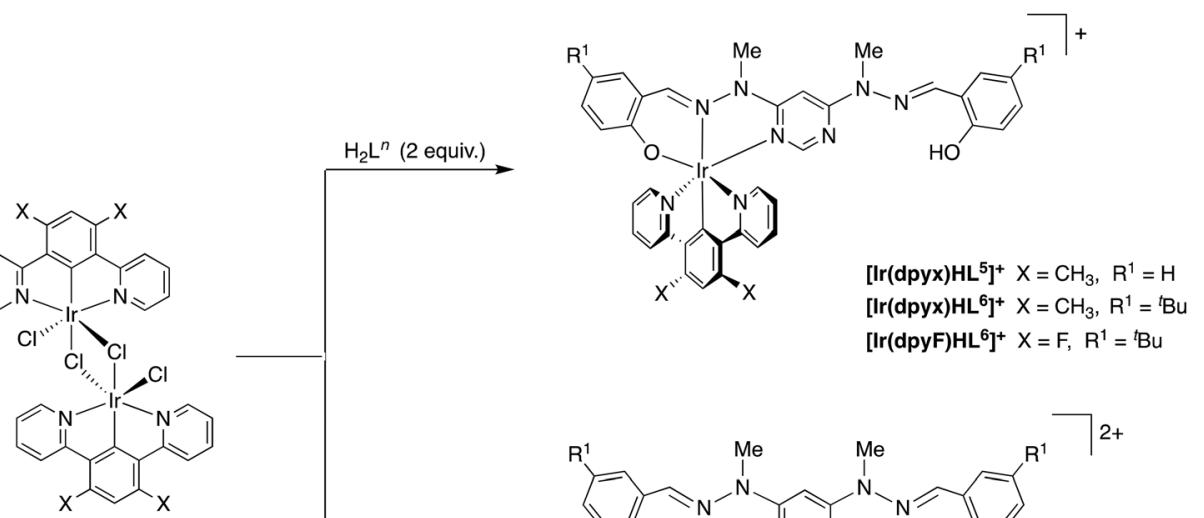

$[\operatorname{II}(\mathrm{dpyx}) \mathrm{Cl}(\mu-\mathrm{Cl})]_{2} \mathrm{X}=\mathrm{CH}_{3}$

$[\operatorname{Ir}(\mathrm{dpyF}) \mathrm{Cl}(u-\mathrm{Cl})]_{2} \mathrm{X}=\mathrm{F}$
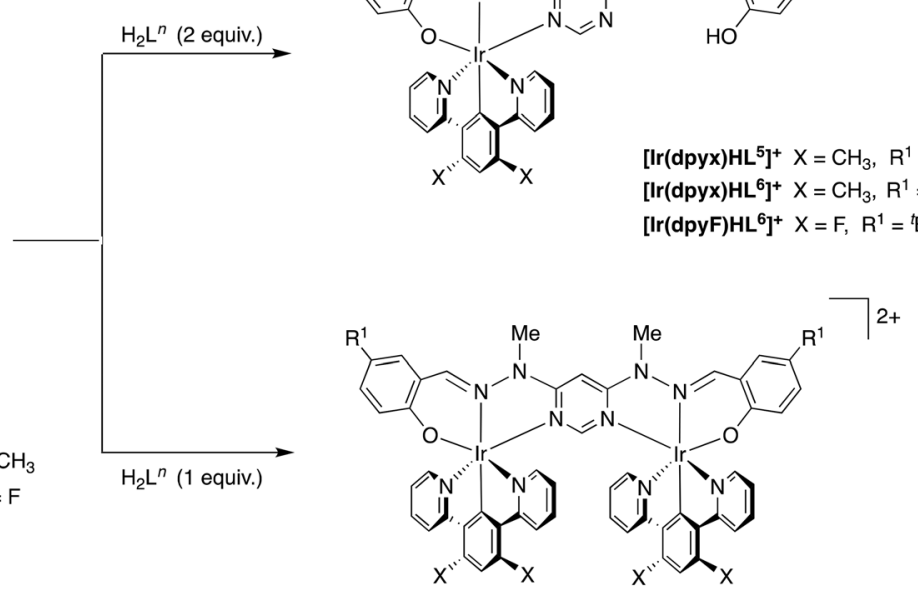

$\left[\{\operatorname{li}(\text { dpyx })\}_{2} \mathrm{~L}^{5}\right]^{2+} \mathrm{X}=\mathrm{CH}_{3}, \mathrm{R}^{1}=\mathrm{H}$

$\left[\{\operatorname{lr}(\text { dpyx })\}_{2} L^{6}\right]^{2+} X=\mathrm{CH}_{3}, R^{1}={ }^{\mathrm{C}} \mathrm{Bu}$

$\left[\{\operatorname{lr}(\mathrm{dpyF})\}_{2} \mathrm{~L}^{6}\right]^{2+} \mathrm{X}=\mathrm{F}, \mathrm{R}^{1}={ }^{\mathrm{t}} \mathrm{Bu}$

Scheme 2 Synthesis of (a) the ditopic, $O^{\wedge} N^{\wedge} N-N^{\wedge} N^{\wedge} O$ proligands and (b) their mono- and dinuclear iridium(III) complexes.

fully obtained (see ESI $\dagger$ ), but we were unable to isolate its dinuclear complex in sufficient purity for photophysical study. Mono- and binuclear complexes incorporating 1,3-dipyridyl- 4,6-difluorobenzene (dpyF, the bis-fluoro analogue of dpyx) were also synthesised for the tert-butyl bridging ligand; i.e., $\left[\operatorname{Ir}(\mathrm{dpyF}) \mathrm{HL}^{5-6}\right] \mathrm{PF}_{6}$ and $\left[\{\operatorname{Ir}(\mathrm{dpyF})\}_{2} \mathrm{~L}^{5-6}\right]\left(\mathrm{PF}_{6}\right)_{2}$ (Scheme $\left.2 \mathrm{~b}\right)$. The 

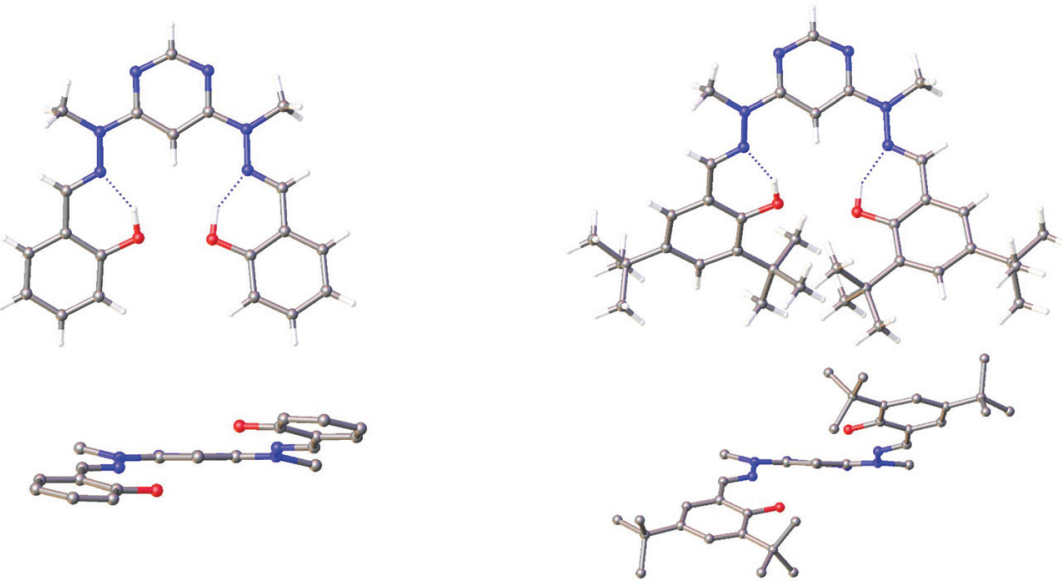

Fig. 2 The molecular structures of $\mathrm{H}_{2} \mathrm{~L}^{5}$ (left) and $\mathrm{H}_{2} \mathrm{~L}^{7}$ (right), viewed from the face of the molecules (top) and from the side (bottom). The packing of the molecules in the two crystals is shown in Fig. $\mathrm{S} 1$ in the ESI. $\dagger$

identity of all six complexes was confirmed by ${ }^{1} \mathrm{H}$ and ${ }^{13} \mathrm{C}$ NMR spectroscopy, mass spectrometry and, for the three dinuclear complexes, by X-ray diffraction (see below).

\section{Structural characterisation}

Crystals of $\mathrm{H}_{2} \mathrm{~L}^{5}$ and $\mathrm{H}_{2} \mathrm{~L}^{7}$ suitable for X-ray diffraction analysis were obtained by slow evaporation of chloroform solutions. The structures confirm the identities of the compounds and show the $\mathrm{O}-\mathrm{H} \cdots \mathrm{N}$ intramolecular hydrogen bonding typical of ortho-iminophenols (Fig. 2 and Fig. $\mathrm{S} 1$ in the ESI†). The $\mathrm{H}_{2} \mathrm{~L}^{5}$ molecule is located on a 2-fold axis. The molecules adopt a spiral conformation with the hydrazone units on opposite sides of the pyrimidine ring, reminiscent of structures reported by Lehn and co-workers for oligomeric hydrazone-pyrimidine. ${ }^{24}$ The dihedral angle between pyrimidine and phenyl cycles is larger in $\mathrm{H}_{2} \mathrm{~L}^{7}$ than $\mathrm{H}_{2} \mathrm{~L}^{5}\left\{30.7^{\circ}\right.$ (av.) versus $\left.13.29(5)^{\circ}\right\}$, evidently as a result of the steric effect of the $t$-butyl substituents in the former.

Small crystals, suitable for X-ray diffraction, of the mononuclear iridium complex $\left[\operatorname{Ir}(\mathrm{dpyx}) \mathrm{L}^{4}\right] \mathrm{PF}_{6}$ were obtained by slow evaporation of the solvent from an acetonitrile solution; the crystal contains one molecule of MeCN per molecule of the complex. The molecular structure in the crystal is shown in Fig. 3, with key bond lengths and angles listed in the caption. The desired, bis-tridentate $\operatorname{Ir}\left(N^{\wedge} C^{\wedge} N\right)\left(N^{\wedge} N^{\wedge} O\right)$ coordination is evident: the $\operatorname{Ir}(\mathrm{III})$ centre exhibits a distorted pseudo-octahedral geometry. The dpyx ligand has an $\mathrm{N}-\mathrm{Ir}-\mathrm{N}$ bite angle of $161.42(6)^{\circ}$, quite typical of tridentate ligands like terpyridine that form two 5-membered chelate rings. The corresponding trans bite angle of $171.71(5)^{\circ}$ in the $N^{\wedge} N^{\wedge} O$-coordinating ligand is significantly larger, reflecting the fact that one of the two chelate rings formed is six-membered in that case. ${ }^{25}$ The Ir-C and Ir- $\mathrm{N}^{\mathrm{py}}$ bond lengths are similar to those of bis-terdentate complexes incorporating dpyx and terpyridine-based ligands. ${ }^{16}$ On the other hand, for the $N^{\wedge} N^{\wedge} O$ ligand, the central Ir- $\mathrm{N}^{\text {hydrazone }}$ bond is significantly longer than the Ir$\mathrm{N}^{\mathrm{py}}$ bond $\{2.078(1)$ and 2.019(1) $\AA$ respectively\}; this contrasts with terpyridine complexes where the $\mathrm{M}-\mathrm{N}$ bond to the central pyridine is normally shorter than those to the lateral pyridines, owing to the constraints of the bite angle. ${ }^{26}$ The shortest inter-

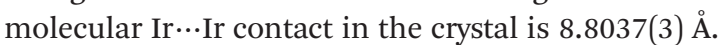

Crystals of the dinuclear complexes $\left[\{\operatorname{Ir}(\mathrm{dpyx})\}_{2} \mathrm{~L}^{5}\right]\left(\mathrm{PF}_{6}\right)_{2}$ and $\left[\{\operatorname{Ir}(\mathrm{dpyx})\}_{2} \mathrm{~L}^{6}\right]\left(\mathrm{PF}_{6}\right)_{2}$ were similarly obtained by slow evaporation of the solvent from acetonitrile solutions, whilst crystals of $\left[\{\operatorname{Ir}(\mathrm{dpyF})\}_{2} \mathrm{~L}^{6}\right]\left(\mathrm{PF}_{6}\right)_{2}$ formed upon diffusion of diethyl ether into an acetonitrile solution. The crystals also contain solvent molecules (see Experimental section and ESI $\dagger$ ). Key bond lengths and angles are given in Table S1 in the ESI. $\dagger$ In all three structures, both of the Ir atoms are hexacoordinated in a distorted pseudo-octahedral geometry, similar to that found in the mononuclear complex $\left[\operatorname{Ir}(\right.$ dpyx $\left.) \mathrm{L}^{4}\right] \mathrm{PF}_{6}$ discussed above and with a similar set of bond lengths and angles. The intermetal-

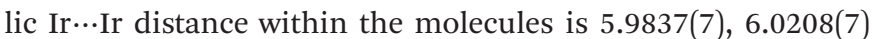
and 5.9426(7) $\AA$ respectively. The $N^{\wedge} C^{\wedge} N$ ligands are tilted relative to one another, with dihedral angles of 33.8(1), 32.4(1) and $35.0(1)^{\circ}$ between their average planes, respectively. It should be noted that the tilt is asymmetric: the intramolecular distances between centroids of juxtaposed pyridine rings on opposite sides of the L-ligand plane are 5.344 and $6.203 \AA$; 4.961 and $6.591 \AA$; and 4.481 and $6.494 \AA$ respectively. In all cases a solvent acetonitrile molecule is wedged into the larger gap between the pyridine rings.

\section{Photophysical properties of the mononuclear complexes $\left[\operatorname{Ir}(\mathbf{d p y x}) \mathbf{L}^{1-4}\right] \mathbf{P F}_{6}$}

UV-visible absorption. The UV-visible absorption spectra of the mononuclear iridium(III) complexes incorporating the pyridylhydrazone ligands, $\left[\operatorname{Ir}(\mathrm{dpyx}) \mathrm{L}^{1-4}\right] \mathrm{PF}_{6}$, were recorded in solution at room temperature (Fig. 4 and Table 1). They show a series of intense bands in the far-UV region, $250-320 \mathrm{~nm}$, attributable to ligand-based $\pi-\pi^{*}$ transitions. Somewhat weaker but nevertheless intense bands with $\varepsilon>8000 \mathrm{M}^{-1} \mathrm{~cm}^{-1}$ are observed in the near-UV region and extending into the visible region $>400 \mathrm{~nm}$. The lowest-energy bands are substantially more intense than those in, for example, $\left[\operatorname{Ir}\left(N^{\wedge} C^{\wedge} N\right)\right.$ 

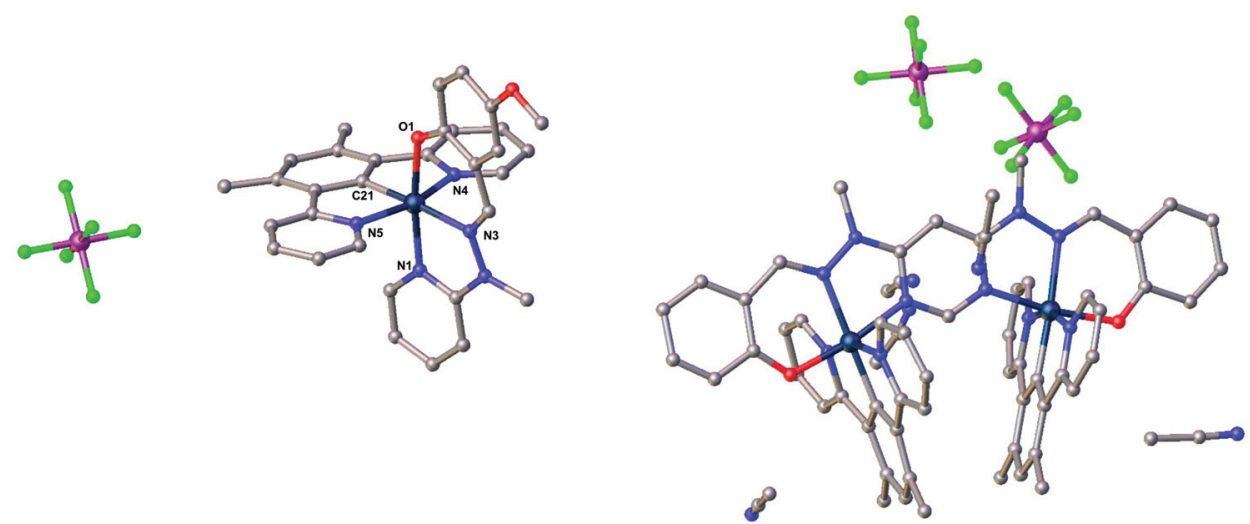

Fig. 3 Left: The molecular structure of the mononuclear complex [Ir(dpyx) $\left.L^{4}\right] P F_{6}$. Key bond lengths $(\AA)$ and angles $\left({ }^{\circ}\right): \operatorname{Ir}-\mathrm{C} 21$ 1.948(2); Ir-N1 2.019(1); Ir-N3 2.078(1) ; Ir-N4 2.035(1); Ir-N5 2.053(1); Ir-O1 2.033(1); N4-Ir1-N5 161.42(6); N3-Ir1-O1 171.70(5); N1-Ir1-C19 175.57(6). Right: The molecular structure of the dinuclear complex $\left[\{\operatorname{Ir}(\mathrm{dpyx})\}_{2} \mathrm{~L}^{5}\right]\left(\mathrm{PF}_{6}\right)_{2}$. For both structures, acetonitrile from the solvent is also present; hydrogen atoms are omitted for clarity; crystal packing diagrams are given in Fig. S2 and S3. $\dagger$ The structures of $\left[\{\operatorname{lr}(\mathrm{dpyx})\}_{2} \mathrm{~L}^{6}\right]\left(\mathrm{PF}_{6}\right)_{2}$ and $\left[\{\mathrm{Ir}(\mathrm{dpyF})\}_{2} \mathrm{~L}^{6}\right]\left(\mathrm{PF}_{6}\right)_{2}$ are similar to $\left[\{\operatorname{lr}(\mathrm{dpyx})\}_{2}{ }^{5}\right]\left(\mathrm{PF}_{6}\right)_{2}$ and are shown in Fig. S4.†

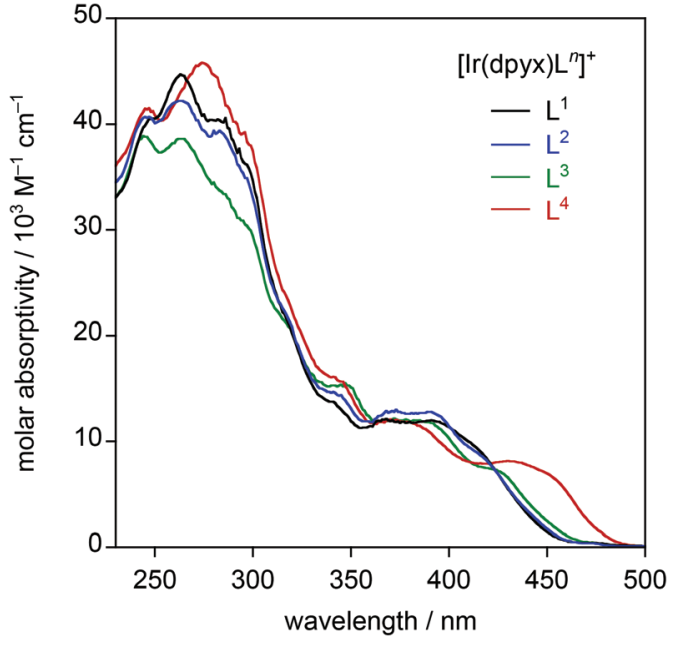

Fig. 4 UV-visible absorption spectra of the series of mononuclear iridium(III) complexes $\left[\operatorname{lr}(\mathrm{dpyx}) \mathrm{L}^{n}\right] \mathrm{PF}_{6}$ in $\mathrm{CH}_{2} \mathrm{Cl}_{2}$ at $295 \mathrm{~K}$.

$\left.\left(N^{\wedge} N^{\wedge} C\right)\right]^{+}$complexes, which have $\varepsilon$ around $5000 \mathrm{M}^{-1} \mathrm{~cm}^{-1}$ in this region, attributed to $\mathrm{d}_{\mathrm{Ir}} \mid \pi_{\mathrm{Ar}} \rightarrow \pi_{\text {py }}^{*}$ charge-transfer transitions. ${ }^{10 a}$ The higher molar absorptivities in the present case no doubt reflect the introduction of additional transitions associated with the hydrazone ligand, as observed in the previously reported $\mathrm{Pt}(\mathrm{II})$ complexes of these ligands, where $\mathrm{d}_{\mathrm{M}} \mid \pi_{\mathrm{ArO}} \rightarrow \pi^{*}{ }_{\text {py }}$ character is invoked. ${ }^{21}$ The introduction of an electron-donating methoxy group para to the phenolate oxygen leads to a distinctive red-shift in the lowest-energy band. As in the Pt(II) complexes, this can be readily understood in terms of an increase in electron density in the metal/phenolate filled orbitals, reducing the frontier orbital gap and hence the energy of the transition to the vacant $\pi^{*}$ orbitals.

Photoluminescence. These first examples of the new class of bis-tridentate iridium(III) complexes are found to be luminescent in solution at ambient temperature, emitting in the orange-to-red region of the spectrum. The spectra in solution at ambient temperature are shown in Fig. 5, and associated data are compiled in Table 1. Some vibrational structure is apparent in each case. The spectrum of $\left[\operatorname{Ir}(\mathrm{dpyx}) \mathrm{L}^{4}\right] \mathrm{PF}_{6}$ is red-shifted by around $1500 \mathrm{~cm}^{-1}$ relative to the parent complex (based on the 0,0 vibrational band maxima), mirroring the trend seen in absorption. There is little variation amongst the other three complexes. The quantum yields in deoxygenated conditions are in the range $7-13 \%$, and lifetimes are of the order $5 \mu$ s. Efficient quenching by dissolved molecular oxygen is observed: the bimolecular quenching rate constants are of the order of $10^{9} \mathrm{M}^{-1} \mathrm{~s}^{-1}$ (Table 1), quite typical values for tripletemitting metal complexes. ${ }^{27}$

It is of interest to determine how the performance of these new complexes compares relative to previously reported monocationic systems incorporating a dipyridylbenzene ligand. A logical comparison is with $[\operatorname{Ir}(\mathrm{dpyx})(\mathrm{phbpy})]^{+}$(phbpyH $=$ 6-phenyl-2,2'-bipyridine; complex 3 in Fig. 1). ${ }^{10 a}$ It features an $N^{\wedge} N^{\wedge} C$-coordinating, cyclometallated ligand, as opposed to the $N^{\wedge} N^{\wedge} O$ coordination of the new complexes. Its emission properties are listed in the final row of Table 1 for comparison. It can be seen that the new $N^{\wedge} N^{\wedge} O$ complexes have somewhat superior quantum yields but substantially longer lifetimes. Some insight into the origins of the differences can be obtained through the estimation of the radiative $k_{\mathrm{r}}$ and nonradiative $\sum k_{\mathrm{nr}}$ decay rate constants from the quantum yields and lifetimes $\{$ see Table 2, footnote (e)\}. From the resulting data in Table 1 , it is evident that $k_{\mathrm{r}}$ is an order of magnitude smaller in the $N^{\wedge} N^{\wedge} O$ complexes. This conclusion is perhaps not unexpected, given that one of the attractions of cyclometallation is the strong $\sigma$ donation associated with the metallated aryl ring which favours the mixing of metal and ligand orbitals and thus enhanced spin-orbit coupling to promote the formally forbidden $\mathrm{T}_{1} \rightarrow \mathrm{S}_{0}$ phosphorescence process. ${ }^{28}$ Nevertheless, $\sum k_{\mathrm{nr}}$ is reduced by a larger factor of up to around 50, which leads to the net enhancement in quantum yields for the set of new complexes. 
Table 1 Photophysical data for the family of mononuclear iridium complexes [Ir(dpyx) $\left.L^{1-4}\right] P F_{6}$ featuring the pyridyl hydrazone ligands. (Data for the related dpyx complex incorporating a tridentate $N^{\wedge} N^{\wedge} C$-coordinating cyclometallated ligand are shown in the final row for comparison)

Absorption $^{a}$ at $295 \mathrm{~K}$

Complex

$\left[\operatorname{Ir}(\operatorname{dpyx}) \mathrm{L}^{1}\right] \mathrm{PF}_{6}$

$\left[\operatorname{Ir}(\right.$ dpyx $\left.) \mathrm{L}^{2}\right] \mathrm{PF}_{6}$

$\left[\operatorname{Ir}(\right.$ dpyx $\left.) \mathrm{L}^{3}\right] \mathrm{PF}_{6}$

$\left[\operatorname{Ir}(\operatorname{dpyx}) \mathrm{L}^{4}\right] \mathrm{PF}_{6}$

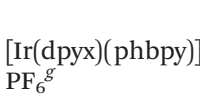
$418 \operatorname{sh}(8360)$

(11 900), $422(7360)$ $430(8140)$ $\lambda_{\max } / \mathrm{nm}\left(\varepsilon / \mathrm{M}^{-1} \mathrm{~cm}^{-1}\right)$

246 (40 200), 264 (44 600), 283 (40 400), 560, 599

367 (12 100), 391 (12 000), 415sh (9240)

246 (40 600), 264 (42 200), 283 (39 400),

340 (14 600), 372 (12 800), 391 (12 800),

245 (38 800), 264 (38 600), 297 (30 400),

317sh (21 200), 344 (15 300), 380

246 (41 400), 273 (45 600), 296sh (39 300), 342 (16 000), 376 (11 900),

240 (24 500), 265 (22 100), 294sh

(16 600), 367 (5360), 411 (5490),

$479(640)$

573,611

614,644

632
Emission at $295 \mathrm{~K}$

\begin{tabular}{lllllll}
\hline$\lambda_{\max } /$ & $\tau^{c /}$ & $\Phi_{\operatorname{lum}}{ }^{d} \times$ & $k_{\mathrm{r}}^{e} /$ & $\sum k_{\mathrm{nr}}{ }^{e} /$ & $k_{\mathrm{q}}^{\mathrm{O}_{2} f /}$ & $\lambda_{\max } /$ \\
$\mathrm{ns}$ & $10^{2}$ & $10^{3} \mathrm{~s}^{-1}$ & $10^{3} \mathrm{~s}^{-1}$ & $10^{9} \mathrm{M}^{-1} \mathrm{~s}^{-1}$ & $\mathrm{~nm}$
\end{tabular}

$\begin{array}{lllllll}n_{\max } / & \mathrm{ns} & 10^{2} & 10^{3} \mathrm{~s}^{-1} & 10^{3} \mathrm{~s}^{-1} & 10^{9} \mathrm{M}^{-1} \mathrm{~s}^{-1} & \mathrm{~nm}\end{array}$

$\begin{array}{lllllll}5400 & 13 & 24 & 160 & 1.4 & 529,576, & 24000\end{array}$

[300]

$4200 \quad 11$

[300]

11

16

210

1.4

$3000 \quad 7.2$

[400]

6200
$[200]$

120

[50]
Emission $^{b}$ at $77 \mathrm{~K}$

632

$537,586, \quad 19000$

643

546, 596, 15000

657

$568,620, \quad 21000$

683

$544,576 \quad 3600$

${ }^{a}$ Maxima at $\lambda>230 \mathrm{~nm}$ are listed. ${ }^{b}$ In diethyl ether/isopentane/ethanol $(2: 2: 1 \mathrm{v} / \mathrm{v}) .{ }^{c}$ Luminescence lifetimes in deoxygenated solution; values in parenthesis refer to air-equilibrated solutions. ${ }^{d}$ Luminescence quantum yield in deoxygenated solution, measured using $\left[\mathrm{Ru}(\mathrm{bpy})_{3}\right] \mathrm{Cl}_{2(\mathrm{aq})}$ as the standard. ${ }^{e} k_{\mathrm{r}}$ and $\sum k_{\mathrm{nr}}$ are the radiative and non-radiative rate constants, estimated from the lifetime and quantum yield, assuming that the emitting state is formed with unitary efficiency: $k_{\mathrm{r}}=\Phi_{\text {lum }} / \tau ; \sum k_{\mathrm{nr}}=\left(1-\Phi_{\mathrm{lum}}\right) / \tau .{ }^{f}$ Bimolecular rate constant for quenching by molecular oxygen estimated from the lifetimes in deoxygenated and air-equilibrated solution, and taking $\left[\mathrm{O}_{2}\right]=2.1 \mathrm{mmol} \mathrm{dm}{ }^{-3}$ in $\mathrm{CH}_{2} \mathrm{Cl}_{2}$ at atmospheric pressure of air at $295 \mathrm{~K} .{ }^{g}$ Data from ref. $10 a$, with $\Phi_{\text {lum }}$ amended using $\Phi_{\text {lum }}=0.040$ for the standard.
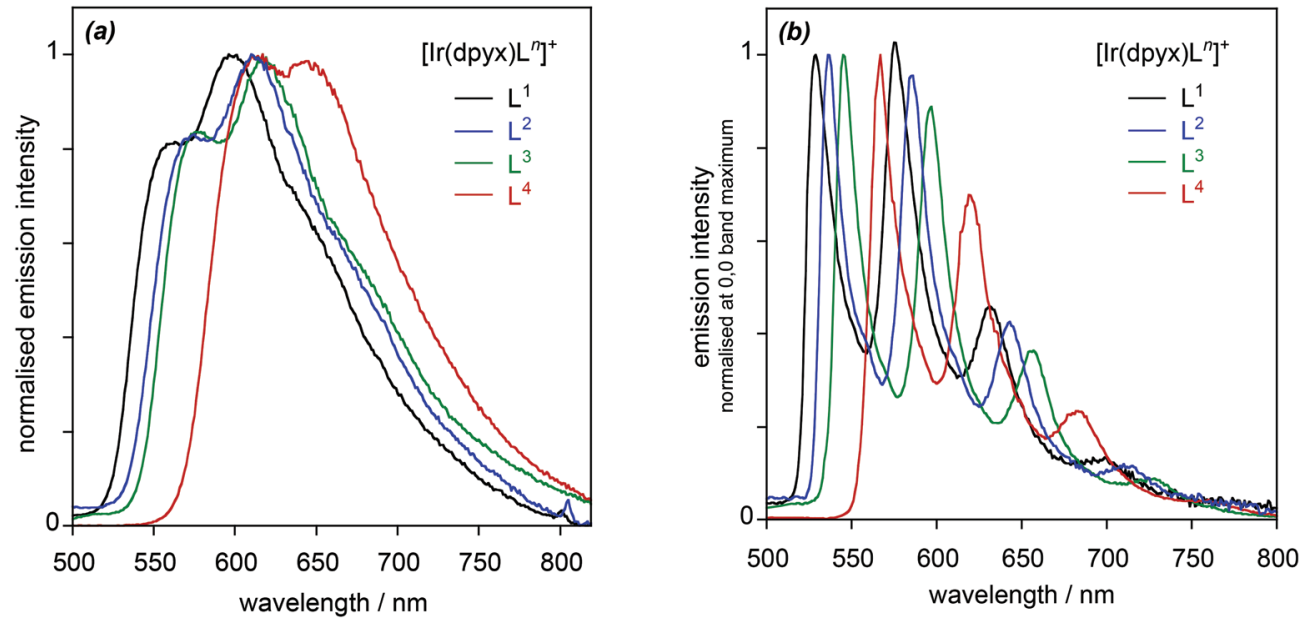

Fig. 5 Normalised photoluminescence spectra of the series of mononuclear iridium(III) complexes [Ir(dpyx) $\left.\mathrm{L}^{n}\right] \mathrm{PF}_{6}:(\mathrm{a})$ in $\mathrm{CH}_{2} \mathrm{Cl}_{2}$ at $295 \mathrm{~K}$; (b) in $\mathrm{EPA}$ at $77 \mathrm{~K}$.

Photophysical properties of the mono- and dinuclear complexes featuring the pyrimidine-based bridging ligand

UV-visible absorption. The absorption spectra of the mononuclear complexes with the pyrimidine ligand, $\left[\operatorname{Ir}(\mathrm{dpyx}) \mathrm{HL}^{5}\right]^{+}$, $\left[\operatorname{Ir}(\text { dpyx }) \mathrm{HL}^{6}\right]^{+}$and $\left[\operatorname{Ir}(\mathrm{dpyF}) \mathrm{HL}^{5}\right]^{+}$(Fig. 6 and Table 2) are quite similar to those of the mononuclear $\left[\operatorname{Ir}(\text { dpyx }) \mathrm{L}^{1-4}\right]^{+}$complexes, as might be anticipated.t The molar absorptivity in the $300-380 \mathrm{~nm}$ region is increased (e.g., by a factor of about 2 at around $360 \mathrm{~nm}$ )

\$Absorption and emission spectra and data for mononuclear complex [Ir(dpyx) $\left.\mathrm{HL}^{7}\right] \mathrm{PF}_{6}$ (the dinuclear analogue of which could not be isolated in high purity) are provided in the ESI. $\dagger$ probably reflecting the additional conjugation in the dihydrazone ligand. The lowest-energy bands are a little red-shifted, as might be expected given the lower-energy of the $\pi^{*}$ orbitals associated with pyrimidine compared to pyridine and the resulting stabilisation of charge-transfer transitions involving the pyrimidine as the acceptor. Interestingly, the change from dpyx to dpyF has little effect on the lowest-energy bands. This contrasts with mononuclear complexes of the form $\left[\operatorname{Ir}\left(N^{\wedge} C^{\wedge} N\right)\left(N^{\wedge} C\right.\right.$-ppy)Cl], where the change from $N^{\wedge} C^{\wedge} N=$ dpyx to dpyF leads to a blue-shift of around $1000 \mathrm{~cm}^{-1}$. The difference in behaviour supports the notion that the excited state predominantly features the $N^{\wedge} N^{\wedge} O$ as opposed to the $N^{\wedge} C^{\wedge} N$ ligand in these new systems. ${ }^{16 c}$ 
Table 2 Photophysical data for dinuclear iridium(III) complexes incorporating pyrimidine-based bridging ligands and their mononuclear analogues

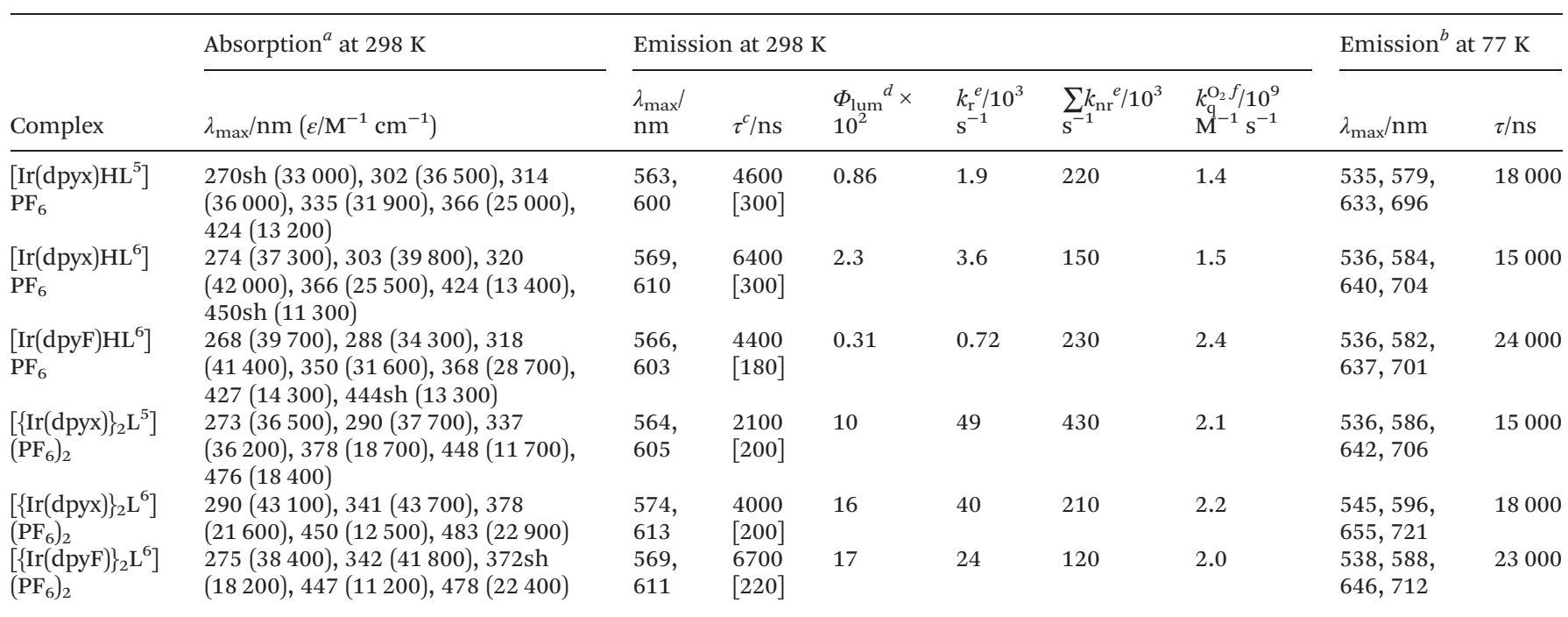

${ }^{a}$ Maxima at $\lambda>230 \mathrm{~nm}$ are listed. ${ }^{b}$ In diethyl ether/isopentane/ethanol $(2: 2: 1 \mathrm{v} / \mathrm{v}) .{ }^{c}$ Luminescence lifetimes in deoxygenated solution; values in parenthesis refer to air-equilibrated solutions. ${ }^{d}$ Luminescence quantum yield in deoxygenated solution, measured using [Ru(bpy) $\left.)_{3}\right] \mathrm{Cl}_{2(\mathrm{aq})}$ as the standard. ${ }^{e} k_{\mathrm{r}}$ and $\sum k_{\mathrm{nr}}$ are the radiative and non-radiative rate constants, estimated from the lifetime and quantum yield, assuming that the emitting state is formed with unitary efficiency: $k_{\mathrm{r}}=\Phi_{\text {lum }} / \tau ; \sum k_{\mathrm{nr}}=\left(1-\Phi_{\text {lum }}\right) / \tau .{ }^{f}$ Bimolecular rate constant for quenching by molecular oxygen estimated from the lifetimes in deoxygenated and air-equilibrated solution, and taking $\left[\mathrm{O}_{2}\right]=2.1 \mathrm{mmol} \mathrm{dm}^{-3}$ in $\mathrm{CH}_{2} \mathrm{Cl}_{2}$ at atmospheric pressure of air at $295 \mathrm{~K}$.

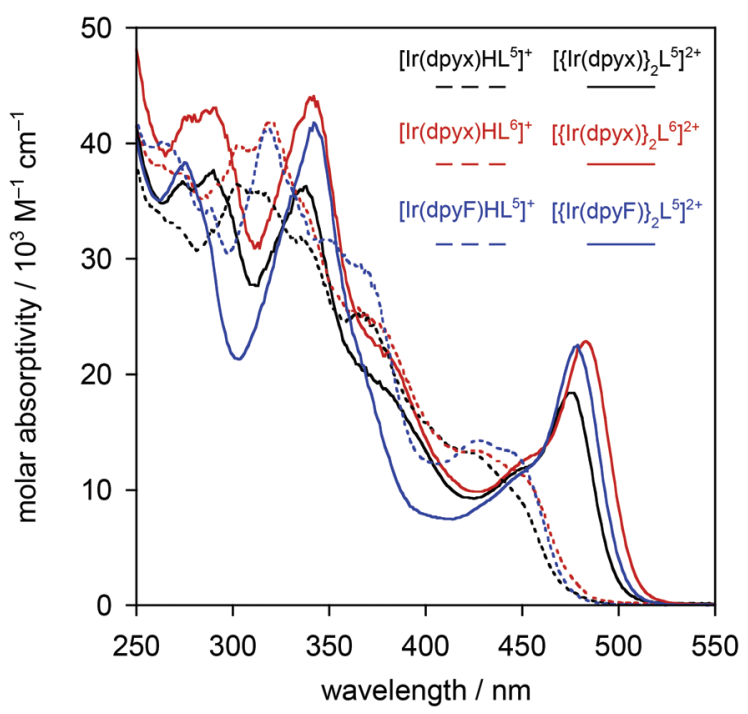

Fig. 6 UV-visible absorption spectra of the dinuclear iridium(III) complexes $\left[\{\operatorname{lr}(\text { dpyx })\}_{2} \mathrm{~L}^{5}\right]^{+}$(black), $\left[\{\operatorname{lr}(\mathrm{dpyx})\}_{2} \mathrm{~L}^{6}\right]^{+}$(red) and $\left[\{\operatorname{lr}(\mathrm{dpyF})\}_{2} \mathrm{~L}^{5}\right]^{+}$ (blue) (solid lines), and of the corresponding complexes with only one iridium(III) bound (dashed lines); $\mathrm{PF}_{6}{ }^{-}$salts in $\mathrm{CH}_{2} \mathrm{Cl}_{2}$ at $295 \mathrm{~K}$.

The absorption spectra of the three dinuclear complexes $\left[\{\operatorname{Ir}(\text { dpyx })\}_{2} \mathrm{~L}^{5}\right]^{2+},\left[\{\operatorname{Ir}(\mathrm{dpyx})\}_{2} \mathrm{~L}^{6}\right]^{2+}$ and $\left[\{\operatorname{Ir}(\mathrm{dpyF})\}_{2} \mathrm{~L}^{5}\right]^{2+}$, are strikingly different from those of the mononuclear analogues (Fig. 6). They each show a very strong, well-defined, lowestenergy band, around $480 \mathrm{~nm}$, significantly red-shifted compared to the lowest-energy absorption of the mononuclear complexes. These bands, with $\varepsilon$ around $20000 \mathrm{M}^{-1} \mathrm{~cm}^{-1}$, are unusually intense compared with those of the lowest-energy bands of most cyclometallated Ir(III) complexes (usually around $5000 \mathrm{M}^{-1} \mathrm{~cm}^{-1}$ ). Similar observations have, however, been made recently for dinuclear Ir(III) and Pt(II) complexes with pyrimidine-based cyclometallated ligands, including 8 and 9 in Fig. 1, and we return to this point below.

Photoluminescence. The emission spectra of the dinuclear complexes and their mononuclear analogues are shown in Fig. 7, and the associated photophysical data are given in Table 2. The spectral profiles of these mononuclear complexes are very similar to those of $\left[\operatorname{Ir}(\mathrm{dpyx}) \mathrm{L}^{1-4}\right]^{+}$with emission maxima again around $560 \mathrm{~nm}$. Apparently, therefore, the energy of the emissive triplet state is little influenced by the change from pyridine to pyrimidine. On the other hand, the quantum yields are reduced by around an order of magnitude: the emission is weak, and this reduction appears to arise largely from a reduction in the radiative rate constant. The dinuclear complexes, in contrast, emit quite brightly, with quantum yields up to $17 \%$. Although the emission maxima are similar to the mononuclear complexes, close inspection reveals two subtle differences (see Fig. S5† for normalised spectra highlighting these differences). Firstly, the width of the band is somewhat narrower for the dinuclear complexes; e.g., the FWHM for $\left[\{\operatorname{Ir}(\operatorname{dpyx})\}_{2} \mathrm{~L}^{5}\right]^{2+}$ is $2900 \mathrm{~cm}^{-1}$ compared to around $3600 \mathrm{~cm}^{-1}$ for $\left[\operatorname{Ir}(\mathrm{dpyx}) \mathrm{L}^{1}\right]^{+}$and $\left[\operatorname{Ir}(\mathrm{dpyx}) \mathrm{HL}^{5}\right]^{+}$. Secondly, the relative intensities of the 0,0 and 0,1 component bands are inverted, with the dinuclear complexes showing a more intense 0,0 band, and vice versa for the mononuclear complexes. Both observations are potentially consistent with a slightly lesser degree of distortion in the excited state in the dinuclear case (smaller Huang-Rhys factor ${ }^{29}$ ). 

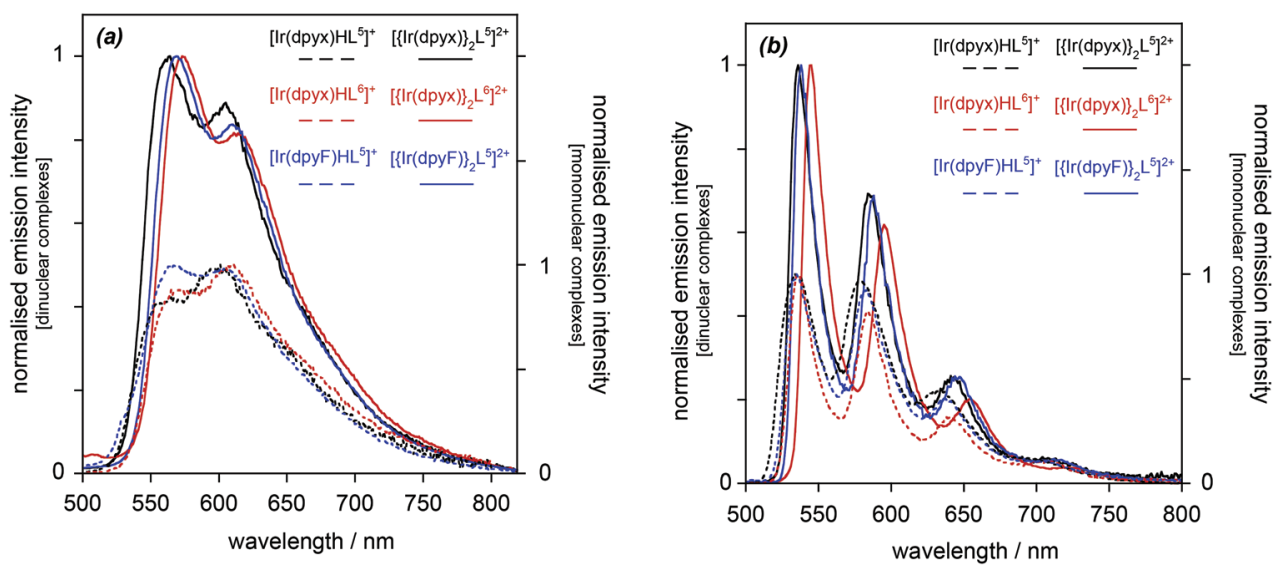

Fig. 7 Normalised photoluminescence spectra of the dinuclear iridium(III) complexes $\left[\{\operatorname{lr}(\text { dpyx })\}_{2} \mathrm{~L}^{5}\right]^{+}\left(\right.$black), $\left[\{\operatorname{lr}(\mathrm{dpyx})\}_{2} \mathrm{~L}^{6}\right]^{+}($red $)$and $\left[\{\operatorname{lr}(\mathrm{dpyF})\}_{2} \mathrm{~L}^{5}\right]^{+}$ (blue) (solid lines), and of the corresponding complexes with one $\operatorname{Ir}\left(\right.$ III) bound (dashed lines), $\mathrm{PF}_{6}{ }^{-}$salts in each case: (a) in $\mathrm{CH}_{2} \mathrm{Cl}_{2}$ at $295 \mathrm{~K}$; (b) in $\mathrm{EPA}$ at $77 \mathrm{~K}$. The mono- and dinuclear series are normalised separately for clarity.

The order-of-magnitude higher radiative rate constants $k_{\mathrm{r}}$ in the dinuclear complexes $\left[\left\{\operatorname{Ir}\left(N^{\wedge} C^{\wedge} N\right)\right\}_{2} \mathrm{~L}^{n}\right]^{2+}$ compared to their mononuclear counterparts $\left[\operatorname{Ir}\left(N^{\wedge} C^{\wedge} N\right) \mathrm{HL}^{n}\right]^{+}$is intriguing, but it mirrors the results of an increasing number of studies with cyclometallating, bridging ligands based on pyrimidines and pyrazines, such as 8 and $\mathbf{9}$ in Fig. 1. Though it may be tempting to attribute the increase to the additional spin-orbit coupling associated with a second metal ion, it is notable that the oscillator strength of the lowest-energy spin-allowed transition is also enhanced significantly, as noted above (Fig. 6), and as it is, too, in systems with bridging cyclometallating ligands like 8 and 9. It is important to note that the SOC process involves coupling of the triplet state to energetically accessible spin-allowed singlet states. The more allowed the latter, the higher the triplet radiative rate constant is expected to be. ${ }^{28}$ Thus, the good performance of the dinuclear complexes in terms of $k_{\mathrm{r}}$ and hence $\Phi_{\text {lum }}$ is likely to be a consequence, at least in part, of the high oscillator strength of the lowest spinallowed transition. ${ }^{30}$

\section{Concluding remarks}

In summary, simple Schiff base chemistry allows pyridyl and phenolate donors to be linked via a central hydrazone unit, generating tridentate $N^{\wedge} N^{\wedge} O$-coordinating ligands that are used for the first time in this study to prepare bis-tridentate complexes of $\operatorname{Ir}(\mathrm{III})$. They offer a readily-synthesised alternative to cyclometallating $N^{\wedge} N^{\wedge} C$ ligands such as 6-phenylbipyridines and, indeed, the simple mononuclear complexes of the form $\left[\operatorname{Ir}(\text { dpyx })\left(N^{\wedge} N^{\wedge} O\right)\right]^{+}$reported here display somewhat superior emission properties to those of $[\operatorname{Ir}(\mathrm{dpyx})(\mathrm{phbpy})]^{+}$. More significantly, the use of 4,6-bis( $N$-methyl-hydrazino)pyrimidine as opposed to $N$-methyl-hydrazinopyridine - provides easy access to ditopic, bis- $N^{\wedge} N^{\wedge} O$-coordinating ligands that are able to bridge two $\operatorname{Ir}(\mathrm{III})$ centres, leading to unprecedented dinuclear complexes in which each metal centre is coordinated in a bis-tridentate manner. The presence of a second metal ion appears to increase the allowedness of both spin-allowed and spin-forbidden transitions, such that the dinuclear complexes absorb unusually strongly in the visible region as well as showing an enhanced rate of phosphorescence. Clearly, these types of Schiff-base ligands may offer considerable scope as alternatives to polypyridyl and cyclometallating ligands such as those based on terpyridines, aryl-bipyridines and related pyrimidine and pyrazine systems.

\section{Experimental details}

\section{General}

Reagents were obtained from commercial sources and used without further purification unless stated otherwise. All solvents used in preparative work were at least Analar grade and water was purified using the Purite STILl $_{\text {plus }}{ }^{\mathrm{TM}}$ system. ${ }^{1} \mathrm{H}$ and ${ }^{13} \mathrm{C}$ NMR spectra were recorded on a Bruker Avance-400 spectrometer. Two-dimensional NMR (COSY, NOESY, HSQC and $\mathrm{HMBC}$ ) spectra were acquired on Varian VNMRS-600 (600 MHz) or VNMRS-700 (700 MHz) instruments. Chemical shifts $(\delta)$ are in ppm, referenced to residual protio-solvent resonances, and coupling constants are given in hertz. Mass spectra were obtained by electrospray ionisation (positive and negative ionisation modes) on a Waters TQD mass spectrometer interfaced with an Acquity UPLC system with acetonitrile as the carrier solvent. Measurements requiring the use of an atmospheric solids analysis probe (ASAP) for ionisation were performed on Waters Xevo QToF mass spectrometer.

\section{X-ray crystallography}

The X-ray single crystal data have been collected using $\lambda \mathrm{MoK} \alpha$ radiation $(\lambda=0.71073 \AA$ ) on an Agilent XCalibur (Sapphire-3 CCD detector, fine-focus sealed tube, graphite monochromator; complex $\mathrm{H}_{2} \mathrm{~L}^{5}$ ) and a Bruker D8Venture (Photon100 CMOS detector, I $\mu \mathrm{S}$-microsource, focusing mirrors; all other com- 
plexes) diffractometers equipped with Cryostream (Oxford Cryosystems) open-flow nitrogen cryostats at the temperature 120.0(2) K. All structures were solved by direct methods and refined by full-matrix least squares on $F^{2}$ for all data using Olex2 ${ }^{31}$ and SHELXTL ${ }^{32}$ software. All non-disordered nonhydrogen atoms were refined anisotropically, hydrogen atoms were placed in the calculated positions and refined in riding mode. It is not always possible in such heavy-atom structures to see electron-density peaks in difference maps which would correspond to acceptable locations for the various solvent $\mathrm{H}$ atoms, so optimisation of the orientation of methyl groups of the solvent molecules was deemed to be unnecessary. Disordered atoms were refined in isotropic approximation with various fixed SOF's. Crystal $\left[\left\{\operatorname{Ir}(\mathrm{dpyx})_{2}\right\} \mathrm{L}^{6}\right]\left(\mathrm{PF}_{6}\right)_{2}$ contains severely disordered $0.5 \mathrm{PF}_{6}$ anion and some solvent molecules the exact number and chemical identity of which could not be found and satisfactory modeled. Their contribution (total $140 e$ per unit cell) has been taken into account by application of the MASK procedure of Olex2 package. Crystal data and parameters of refinement are listed in Table 3. Crystallographic data for the six structures have been deposited with the Cambridge Crystallographic Data Centre as supplementary publications CCDC 2006844-2006849. $\dagger$

\section{Solution-state photophysics}

UV-visible absorption spectra were recorded on a Biotek Instruments UVIKON XS spectrometer operating with LabPower software. Emission spectra were acquired on a Jobin Yvon Fluoromax-2 spectrometer equipped with a Hamamatsu R928 photomultiplier tube. All samples were contained within $1 \mathrm{~cm}$ pathlength quartz cuvettes modified for connection to a vacuum line. Degassing was achieved by at least three freezepump-thaw cycles whilst connected to the vacuum manifold: final vapour pressure at $77 \mathrm{~K}$ was $<5 \times 10^{-2}$ mbar. Emission was recorded at $90^{\circ}$ to the excitation source, and spectra were corrected after acquisition for dark count and for the spectral response of the detector. The quantum yields were determined relative to an aqueous solution of $\left[\mathrm{Ru}(\mathrm{bpy})_{3}\right] \mathrm{Cl}_{2}$, for which $\Phi_{\text {lum }}=0.040 . .^{33}$ Emission spectra at $77 \mathrm{~K}$ were recorded in $4 \mathrm{~mm}$ diameter tubes held within a liquid-nitrogen-cooled quartz dewar, using the same spectrometer.

The luminescence lifetimes in solution at $295 \mathrm{~K}$ were measured by time-correlated single-photon counting, using an EPL405 pulsed-diode laser as excitation source (405 $\mathrm{nm}$ excitation, pulse length of $60 \mathrm{ps}$, repetition rate $20 \mathrm{kHz}$ ). The emission was detected at $90^{\circ}$ to the excitation source, after passage through a monochromator, using an R928 PMT thermoelectrically cooled to $-20{ }^{\circ} \mathrm{C}$. The luminescence lifetimes at $77 \mathrm{~K}$ were recorded using the same detector operating in multichannel scaling mode, following excitation with a pulsed xenon lamp.

\section{Synthetic and characterisation details for representative proligands and complexes}

Proligands $\mathrm{HL}^{1}-\mathrm{HL}^{4}$ were prepared by condensation of $N$-methylhydrazinopyridine with the appropriate salicylaldehyde, as described in our earlier work on Pt(II) complexes. ${ }^{21}$ Starting materials for the preparation of the ditopic ligands were obtained from commercial suppliers and used as supplied. Details are given below, and the numbering system for the assignment of NMR resonances is provided in Fig. 8. The preparation of $\mathrm{H}_{2} \mathrm{~L}^{7}$ and its mononuclear $\operatorname{Ir}(\mathrm{III})$ complex are described in the ESI. $\dagger$

4,6-Bis(1-methylhydrazino)pyrimidine.

$4,6-$ Dichloropyrimidine (720 mg, $4.83 \mathrm{mmol})$ was stirred in methylhydrazine $(10 \mathrm{~mL})$ at reflux under argon for $2 \mathrm{~h}$. Water $(20 \mathrm{~mL})$ was added, and the product was extracted into DCM $(3 \times 10 \mathrm{~mL})$. The organic layer was dried over anhydrous

Table 3 Crystal data and structure refinement parameters

\begin{tabular}{|c|c|c|c|c|c|c|}
\hline Compound & $\mathrm{H}_{2} \mathrm{~L}^{5}$ & $\mathrm{H}_{2} \mathrm{~L}^{7}$ & {$\left[\operatorname{Ir}(\right.$ dpyx $\left.) \mathrm{L}^{4}\right] \mathrm{PF}_{6}$} & {$\left[\{\operatorname{Ir}(\text { dpyx })\}_{2} \mathrm{~L}^{5}\right]\left(\mathrm{PF}_{6}\right)_{2}$} & {$\left[\{\operatorname{Ir}(\mathrm{dpyx})\}_{2} \mathrm{~L}^{6}\right]\left(\mathrm{PF}_{6}\right)_{2}$} & {$\left[\{\operatorname{Ir}(\mathrm{dpyF})\}_{2} \mathrm{~L}^{6}\right]\left(\mathrm{PF}_{6}\right)_{2}$} \\
\hline Empirical formula & $\mathrm{C}_{20} \mathrm{H}_{20} \mathrm{~N}_{6} \mathrm{O}_{2}$ & $\mathrm{C}_{36} \mathrm{H}_{52} \mathrm{~N}_{6} \mathrm{O}_{2}$ & $\mathrm{C}_{34} \mathrm{H}_{32} \mathrm{~F}_{6} \mathrm{IrN}_{6} \mathrm{O}_{2} \mathrm{P}$ & $\mathrm{C}_{64} \mathrm{H}_{60} \mathrm{~F}_{12} \mathrm{Ir}_{2} \mathrm{~N}_{14} \mathrm{O}_{2} \mathrm{P}_{2}$ & $\mathrm{C}_{141} \mathrm{H}_{150} \mathrm{~F}_{18} \mathrm{Ir}_{4} \mathrm{~N}_{26} \mathrm{O}_{5} \mathrm{P}_{3}$ & $\mathrm{C}_{70} \mathrm{H}_{71} \mathrm{~F}_{16} \mathrm{Ir}_{2} \mathrm{~N}_{13} \mathrm{O}_{3} \mathrm{P}_{2}$ \\
\hline Formula weight & 376.42 & 600.83 & 893.83 & 1731.60 & 3492.57 & 1892.73 \\
\hline Crystal system & Monoclinic & Triclinic & Monoclinic & Triclinic & Triclinic & Triclinic \\
\hline Space group & $I 2 / c$ & $P \overline{1}$ & $P 2_{1} / c$ & $P \overline{1}$ & $P \overline{1}$ & $P \overline{1}$ \\
\hline$a / \AA$ & $15.5025(12)$ & $12.1186(12)$ & $11.4532(5)$ & $12.7200(11)$ & $12.2674(11)$ & $12.4261(12)$ \\
\hline$b / \AA$ & $10.4734(8)$ & $12.2241(10)$ & $15.8034(7)$ & $14.3155(12)$ & $16.3422(15)$ & $15.8044(15)$ \\
\hline$c / \AA$ & $11.3532(9)$ & $12.9851(11)$ & $18.1543(8)$ & $19.9170(17)$ & $21.227(2)$ & $19.8347(19)$ \\
\hline$\alpha /^{\circ}$ & 90 & $72.172(3)$ & 90.00 & $86.983(3)$ & $75.235(3)$ & $76.196(3)$ \\
\hline$\beta /{ }^{\circ}$ & $93.231(7)$ & $77.714(3)$ & $95.0909(16)$ & $79.538(3)$ & $76.582(3)$ & $74.210(3)$ \\
\hline$\gamma /{ }^{\circ}$ & 90 & $88.934(3)$ & 90.00 & $78.218(2)$ & $87.493(3)$ & $81.438(3)$ \\
\hline Volume $/ \AA^{3}$ & $1840.4(3)$ & $1787.0(3)$ & $3273.0(2)$ & $3490.9(5)$ & $4002.2(6)$ & $3625.3(6)$ \\
\hline$Z$ & 4 & 2 & 4 & 2 & 1 & 2 \\
\hline$\rho_{\text {calc }}, \mathrm{g} \mathrm{cm}^{-3}$ & 1.359 & 1.117 & 1.814 & 1.647 & 1.449 & 1.734 \\
\hline$\mu / \mathrm{mm}^{-1}$ & 0.092 & 0.070 & 4.206 & 3.939 & 3.422 & 3.809 \\
\hline$F(000)$ & 792.0 & 652.0 & 1760.0 & 1700.0 & 1733.0 & 1868.0 \\
\hline Reflections collected & 15142 & 28016 & 71211 & 74344 & 83046 & 64406 \\
\hline Independent refl., $R_{\text {int }}$ & $\begin{array}{l}2446 \\
0.1019\end{array}$ & $\begin{array}{l}9488, \\
0.0442\end{array}$ & $9548,0.0310$ & $16016,0.1680$ & $21245,0.0351$ & $15791,0.1711$ \\
\hline $\begin{array}{l}\text { Data/restraints/ } \\
\text { parameters }\end{array}$ & $2446 / 0 / 133$ & $9488 / 2 / 417$ & $9548 / 0 / 456$ & 16 016/914/872 & $21245 / 64 / 891$ & 15 791/198/966 \\
\hline Goodness-of-fit on $F^{2}$ & 1.020 & 1.021 & 1.054 & 0.958 & 1.053 & 0.989 \\
\hline Final $R_{1}[I \geq 2 \sigma(I)]$ & 0.0565 & 0.0556 & 0.0161 & 0.0735 & 0.0484 & 0.0640 \\
\hline Final $w R_{2}$ [all data] & 0.1299 & 0.1369 & 0.0367 & 0.1700 & 0.1166 & 0.1398 \\
\hline
\end{tabular}



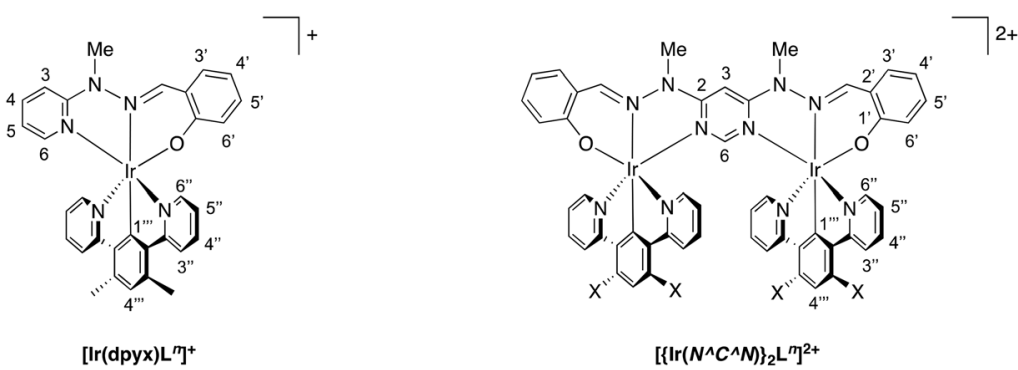

Fig. 8 Numbering system for NMR assignments.

$\mathrm{MgSO}_{4}$ and the solvent removed under reduced pressure to give the product as a cream solid (702 mg, $4.17 \mathrm{mmol}, 86 \%$ yield). The experimental data obtained were in agreement with those reported in literature.

$\mathbf{H}_{2} \mathbf{L}^{5}$. Salicylaldehyde (254 mg, $2.08 \mathrm{mmol}$ ) was added slowly to a stirred solution of 4,6-bis(1-methyl-hydrazino)pyrimidine $(175 \mathrm{mg}, 1.04 \mathrm{mmol})$ in $\mathrm{MeOH}(5 \mathrm{~mL})$. The yellow solution was stirred under argon at reflux for $1 \mathrm{~h}$ before cooling to ambient temperature. The resulting lemon slurry was filtered and washed with cold methanol to yield the product as a cream powder (295 mg, $0.78 \mathrm{mmol}, 75 \%$ yield). ${ }^{1} \mathrm{H} \mathrm{NMR}\left(\mathrm{CDCl}_{3}\right.$, $700 \mathrm{MHz}): 10.98\left(2 \mathrm{H}, \mathrm{s}, \mathrm{H}^{\mathrm{OH}}\right), 8.48\left(1 \mathrm{H}, \mathrm{s}, \mathrm{H}^{6}\right), 7.90(2 \mathrm{H}, \mathrm{s}$, $\left.\mathrm{H}^{\text {imine }}\right), 7.28-7.26\left(4 \mathrm{H}, \mathrm{m}, \mathrm{H}^{3^{\prime}}+\mathrm{H}^{4^{\prime}}\right), 7.04\left(2 \mathrm{H}, \mathrm{d}, J=9, \mathrm{H}^{6^{\prime}}\right)$, $6.91\left(2 \mathrm{H}, \mathrm{td}, J=7.5\right.$ and $\left.1, \mathrm{H}^{5^{\prime}}\right), 6.80\left(1 \mathrm{H}, \mathrm{s}, \mathrm{H}^{3}\right), 3.66(6 \mathrm{H}, \mathrm{s}$, $\left.\mathrm{H}^{\mathrm{NMe}}\right) .{ }^{13} \mathrm{C} \mathrm{NMR}\left(\mathrm{CDCl}_{3}, 176 \mathrm{MHz}\right): 162.0\left(\mathrm{C}^{6}\right), 157.6\left(\mathrm{C}^{1^{\prime}}\right)$, $157.3\left(\mathrm{C}^{6}\right), 141.6\left(\mathrm{C}^{\text {imine }}\right), 130.7\left(\mathrm{C}^{3^{\prime}}\right.$ and $\left.\mathrm{C}^{4^{\prime}}\right), 119.5\left(\mathrm{C}^{5^{\prime}}\right), 118.8$ $\left(\mathrm{C}^{2^{\prime}}\right), 117.1\left(\mathrm{C}^{6^{\prime}}\right), 85.7\left(\mathrm{C}^{3}\right), 30.0\left(\mathrm{C}^{\mathrm{NMe}}\right)$. MS (ES-): $\mathrm{m} / \mathrm{z} 375[\mathrm{M}-$ $\mathrm{H}]^{-}$; HRMS (ES-): $\mathrm{m} / \mathrm{z} 375.1583[\mathrm{M}-\mathrm{H}]^{-}$; calculated for $\left[\mathrm{C}_{20} \mathrm{H}_{19} \mathrm{~N}_{6} \mathrm{O}_{2}\right]^{+} 375.1569$.

$\mathbf{H}_{2} \mathbf{L}^{6}$. This compound was prepared in a similar way to $\mathrm{H}_{2} \mathrm{~L}^{5}$ starting from 5-tert-butyl-2-hydroxy-benzaldehyde $(210 \mathrm{mg}$, $1.18 \mathrm{mmol}$ ) and 4,6-bis(1-methylhydrazino)pyrimidine $(100 \mathrm{mg}, 0.59 \mathrm{mmol})$ in $\mathrm{MeOH}(6 \mathrm{ml})$, the final product being again isolated as a cream powder $(247 \mathrm{mg}, 0.51 \mathrm{mmol}, 86 \%$ yield). ${ }^{1} \mathrm{H} \mathrm{NMR}\left(\mathrm{CDCl}_{3}, 700 \mathrm{MHz}\right): 10.80\left(2 \mathrm{H}, \mathrm{s}, \mathrm{H}^{\mathrm{OH}}\right), 8.49$ $\left(1 \mathrm{H}, \mathrm{d}, J=7, \mathrm{H}^{6}\right), 7.96\left(2 \mathrm{H}, \mathrm{s}, \mathrm{H}^{\text {imine }}\right), 7.31(2 \mathrm{H}, \mathrm{dd}, J=8.5$ and 2.5, $\left.\mathrm{H}^{5^{\prime}}\right), 7.27\left(1 \mathrm{H}, \mathrm{s}, \mathrm{H}^{3^{\prime}}\right), 6.98\left(2 \mathrm{H}, \mathrm{d}, J=9, \mathrm{H}^{6^{\prime}}\right), 6.84(1 \mathrm{H}, \mathrm{d}$, $\left.J=1, \mathrm{H}^{3}\right), 3.70\left(6 \mathrm{H}, \mathrm{s}, \mathrm{H}^{\mathrm{NMe}}\right), 1.33\left(18 \mathrm{H}, \mathrm{s}, \mathrm{H}^{t \text {-butyl }}\right) .{ }^{13} \mathrm{C}$ NMR $\left(\mathrm{CDCl}_{3}, 176 \mathrm{MHz}\right): 162.1\left(\mathrm{C}^{2}\right), 155.4\left(\mathrm{C}^{6}\right), 142.3\left(\mathrm{C}^{1^{\prime}}\right), 142.2$ $\left(\mathrm{C}^{\text {imine }}\right), 128.2\left(\mathrm{C}^{5^{\prime}}\right), 127.3\left(\mathrm{C}^{3^{\prime}}\right), 125.3\left(\mathrm{C}^{4^{\prime}}\right), 118.0\left(\mathrm{C}^{2^{\prime}}\right), 116.7$ $\left(\mathrm{C}^{6^{\prime}}\right), 85.79\left(\mathrm{C}^{3}\right), 34.2\left(\mathrm{C}^{7^{\prime}}\right), 31.6\left(\mathrm{C}^{t \text {-butyl }}\right), 30.1\left(\mathrm{C}^{\mathrm{NMe}}\right)$. MS (ES+): $m / z 489[\mathrm{M}+\mathrm{H}]^{+}$; HRMS (ES+): $m / z 489.2965[\mathrm{M}+\mathrm{H}]^{+}$; calculated for $\left[\mathrm{C}_{28} \mathrm{H}_{37} \mathrm{~N}_{6} \mathrm{O}_{2}\right]^{+} 489.2978$.

$\left[\operatorname{Ir}(\mathbf{d p y x}) \mathbf{L}^{1}\right] \mathbf{P F}_{\mathbf{6}}$. A mixture of $\mathrm{HL}^{1}(24 \mathrm{mg}, 0.11 \mathrm{mmol})$ and [Ir (dpyx) $\left.\mathrm{Cl}(\mu-\mathrm{Cl})_{2}\right]_{2}(50 \mathrm{mg}, 0.05 \mathrm{mmol})$ in ethylene glycol $(1.5 \mathrm{~mL})$ was heated to $195^{\circ} \mathrm{C}$ for $90 \mathrm{~min}$ under argon. The resulting brown slurry was diluted with $\mathrm{H}_{2} \mathrm{O}(2 \mathrm{~mL})$ and pipetted into a saturated aqueous solution of $\mathrm{KPF}_{6}$ to produce a bright yellow solid. The crude material was isolated by centrifugation, washed with $\mathrm{H}_{2} \mathrm{O}$ $(3 \times 5 \mathrm{~mL})$, and recrystallized from acetone/hexane to yield the desired product (31 mg, $0.04 \mathrm{mmol}, 34 \%$ yield).

${ }^{1} \mathrm{H}$ NMR (DMSO-d 6 , $\left.700 \mathrm{MHz}\right): 9.01(1 \mathrm{H}, \mathrm{s}), 8.21(2 \mathrm{H}, \mathrm{d}, J=$ 2.5, $\left.\mathrm{H}^{6^{\prime \prime}}\right), 7.87\left(2 \mathrm{H}, \mathrm{t}, J=8, \mathrm{H}^{5^{\prime \prime}}\right), 7.79-7.78\left(3 \mathrm{H}, \mathrm{m}, \mathrm{H}^{3^{\prime \prime}}\right.$ or $\left.\mathrm{H}^{3}\right)$, $7.64\left(1 \mathrm{H}, \mathrm{ddd}, J=9,7\right.$ and $\left.1.5, \mathrm{H}^{4^{\prime}}\right), 7.48\left(1 \mathrm{H}, \mathrm{d}, J=9, \mathrm{H}^{3^{\prime}}\right), 7.15$ $\left(1 \mathrm{H}, \mathrm{s}, \mathrm{H}^{4^{\prime \prime \prime}}\right), 7.11\left(2 \mathrm{H}, \mathrm{t}, J=6.5, \mathrm{H}^{4^{\prime \prime}}\right), 7.00(1 \mathrm{H}, \mathrm{ddd}, J=8,7$ and $\left.2, \mathrm{H}^{5}\right), 6.86\left(1 \mathrm{H}, \mathrm{d}, J=6, \mathrm{H}^{6^{\prime}}\right), 6.62\left(1 \mathrm{H}, \mathrm{t}, J=7, \mathrm{H}^{4}\right), 6.57$ $(1 \mathrm{H}, \mathrm{t}, J=7), 6.43(1 \mathrm{H}, \mathrm{d}, J=8.5), 4.20\left(3 \mathrm{H}, \mathrm{s}, \mathrm{H}^{\mathrm{NMe}}\right), 2.85(6 \mathrm{H}$, $\mathrm{s}, \mathrm{H}^{\mathrm{Me}}$ ). ${ }^{13} \mathrm{C}$ NMR (DMSO-d 6 , $176 \mathrm{MHz}$ ): 178.7, 168.9, 160.8, 154.5 , 150.4, 149.6, 139.8, 139.2, 138.0, 137.9, 137.6, 135.0, $131.5,131.4,123.8,123.2,121.8,119.5,116.6,115.1,109.3$, 33.7, 21.9. MS (ES+): $m / z 678[\mathrm{M}]^{+}$; HRMS (ES+): $m / z 676.1840$ $[\mathrm{M}]^{+}$; calculated for $\left[\mathrm{C}_{31} \mathrm{H}_{27} \mathrm{~N}_{5} \mathrm{OIr}\right]^{+}$676.1822.

$\left[\operatorname{Ir}(\mathbf{d p y x}) \mathbf{L}^{2}\right] \mathbf{P F}_{\mathbf{6}}$. This complex was prepared similarly, using $\mathrm{HL}^{2}$ (30 mg, $0.11 \mathrm{mmol}$ ) in place of $\mathrm{HL}^{1}$, giving the desired product as a bright yellow solid (47 mg, $0.05 \mathrm{mmol}, 47 \%$ yield). ${ }^{1} \mathrm{H}$ NMR ( $\left.\mathrm{CD}_{3} \mathrm{CN}, 700 \mathrm{MHz}\right): 8.81\left(1 \mathrm{H}, \mathrm{s}, \mathrm{H}^{\text {imine }}\right), 8.23$ $\left(2 \mathrm{H}, \mathrm{d}, J=8.5, \mathrm{H}^{6 "}\right), 7.82\left(2 \mathrm{H}, \mathrm{ddd}, J=8,7.5\right.$ and $\left.1.5, \mathrm{H}^{5 "}\right)$, $7.70-7.68\left(3 \mathrm{H}, \mathrm{m}, \mathrm{H}^{3^{\prime}}\right.$ and $\left.\mathrm{H}^{3^{\prime \prime}}\right), 7.80(1 \mathrm{H}, \mathrm{ddd}, J=8.5,7$ and 1.5, $\left.\mathrm{H}^{5}\right), 7.22\left(1 \mathrm{H}, \mathrm{d}, J=9, \mathrm{H}^{6}\right), 7.18\left(1 \mathrm{H}, \mathrm{s}, \mathrm{H}^{4^{\prime \prime \prime}}\right), 7.05-7.00$ $\left(4 \mathrm{H}, \mathrm{m}, \mathrm{H}^{3}, \mathrm{H}^{5^{\prime}}\right.$ and $\left.\mathrm{H}^{4^{\prime \prime}}\right), 6.50\left(1 \mathrm{H}, \mathrm{ddd}, J=8,6\right.$ and $\left.1, \mathrm{H}^{4}\right)$, $6.47\left(1 \mathrm{H}, \mathrm{d}, J=9, \mathrm{H}^{6^{\prime}}\right), 4.11\left(3 \mathrm{H}, \mathrm{s}, \mathrm{H}^{\mathrm{NMe}}\right), 2.89\left(6 \mathrm{H}, \mathrm{s}, \mathrm{H}^{\mathrm{Me}}\right)$. ${ }^{13} \mathrm{C}$ NMR $\left(\mathrm{CD}_{3} \mathrm{CN}, 176 \mathrm{MHz}\right): 177.7,169.5,159.9,150.4,139.8$, $138.8,138.0$, 137.9, 137.8, 131.8, 126.1, 125.0, 124.1, 122.9, 119.3, 117.5, 117.3, 109.4, 33.8, 21.5. MS (ES+): $m / z 762[\mathrm{M}]^{+}$; HRMS (ES+): $\quad m / z \quad 760.1632 \quad[\mathrm{M}]^{+}$; calculated for $\left[\mathrm{C}_{32} \mathrm{H}_{26} \mathrm{~N}_{5} \mathrm{O}_{2} \mathrm{~F}_{3} \mathrm{Ir}\right]^{+} 760.1645$.

$\left[\operatorname{Ir}(\mathbf{d p y x}) \mathbf{L}^{3}\right] \mathbf{P F}_{\mathbf{6}}$. This complex was prepared similarly, using $\mathrm{HL}^{3}(12 \mathrm{mg}, 0.04 \mathrm{mmol})$ in place of $\mathrm{HL}^{1}$, with $[\operatorname{Ir}(\operatorname{dpyx}) \mathrm{Cl}(\mu-$ $\left.\mathrm{Cl})_{2}\right]_{2}(20 \mathrm{mg}, 0.02 \mathrm{mmol})$, giving the desired product as a bright yellow solid (18 mg, $0.02 \mathrm{mmol}$, 99\% yield). ${ }^{1} \mathrm{H}$ NMR (DMSO-d $6,600 \mathrm{MHz}): 9.10\left(1 \mathrm{H}, \mathrm{s}, \mathrm{H}^{\text {imine }}\right), 8.24(2 \mathrm{H}, \mathrm{d}, J=8$, $\left.\mathrm{H}^{6^{\prime \prime}}\right), 7.98\left(1 \mathrm{H}, \mathrm{d}, J=3, \mathrm{H}^{5^{\prime}}\right), 7.92\left(2 \mathrm{H}, \mathrm{t}, J=8, \mathrm{H}^{5^{\prime \prime}}\right), 7.83(2 \mathrm{H}$, $\mathrm{dd}, J=6$ and $\left.1, \mathrm{H}^{3 \prime}\right), 7.70\left(1 \mathrm{H}\right.$, ddd, $J=9,7$ and $\left.1.5, \mathrm{H}^{5}\right), 7.55$ $\left(1 \mathrm{H}, \mathrm{d}, J=9, \mathrm{H}^{6}\right), 7.35\left(1 \mathrm{H}, \mathrm{d}, J=3, \mathrm{H}^{3^{\prime}}\right), 7.18\left(1 \mathrm{H}, \mathrm{s}, \mathrm{H}^{4^{\prime \prime \prime}}\right), 7.15$ $\left(1 \mathrm{H}\right.$, ddd, $J=7.5,6$ and $\left.1, \mathrm{H}^{4^{\prime \prime}}\right), 6.85\left(1 \mathrm{H}, \mathrm{dd}, J=6\right.$ and $\left.1, \mathrm{H}^{3}\right)$, $6.65\left(1 \mathrm{H}, \mathrm{t}, J=7, \mathrm{H}^{4}\right), 4.21\left(3 \mathrm{H}, \mathrm{s}, \mathrm{H}^{\mathrm{NMe}}\right), 2.88\left(6 \mathrm{H}, \mathrm{s}, \mathrm{H}^{\mathrm{Me}}\right) .{ }^{13} \mathrm{C}$ NMR (DMSO-d $6151 \mathrm{MHz}$ ): 177.7, 168.8, 154.7, 153.9, 150.6, $149.6,140.1,138.3,128.1,138.0,137.4,132.4,131.8,130.1$, 126.3, 123.8, 123.3, 121.7, 118.1, 117.2, 117.1, 109.6, 34.0, 30.7, 21.9. MS (ES+): $m / z 746[\mathrm{M}]^{+}$; HRMS (ES+): $m / z 744.1039[\mathrm{M}]^{+}$; calculated for $\left[\mathrm{C}_{31} \mathrm{H}_{25} \mathrm{~N}_{5} \mathrm{O}_{2} \mathrm{Cl}_{2} \mathrm{Ir}\right]^{+}$744.1042.

$\left[\operatorname{Ir}(\mathbf{d p y x}) \mathbf{L}^{\mathbf{4}}\right] \mathbf{P F}_{\mathbf{6}}$. This complex was prepared similarly, using $\mathrm{HL}^{4}(25 \mathrm{mg}, 0.11 \mathrm{mmol})$ in place of $\mathrm{HL}^{1}$. The crude material was recrystallized from $\mathrm{MeCN} / \mathrm{Et}_{2} \mathrm{O}$ to yield the desired product as a bright yellow solid (55 mg, $0.06 \mathrm{mmol}, 59 \%$ yield). ${ }^{1} \mathrm{H}$ NMR ( $\left.\mathrm{CD}_{3} \mathrm{CN}, 700 \mathrm{MHz}\right): 8.83$ (1H, s, Himine $), 8.21$ 
$\left(1 \mathrm{H}, \mathrm{d}, J=2, \mathrm{H}^{6 "}\right), 7.79\left(2 \mathrm{H}, \mathrm{ddd}, J=9,7\right.$ and $\left.2, \mathrm{H}^{5^{\prime \prime}}\right), 7.68(2 \mathrm{H}$, ddd, $J=6,2$ and 1, $\left.\mathrm{H}^{3 \prime}\right), 7.58-7.56\left(1 \mathrm{H}, \mathrm{m}, \mathrm{H}^{5}\right), 7.24(1 \mathrm{H}, \mathrm{d}, J=$ $\left.3, \mathrm{H}^{3^{\prime}}\right), 7.19\left(1 \mathrm{H}, \mathrm{d}, J=9, \mathrm{H}^{6}\right), 7.16\left(1 \mathrm{H}, \mathrm{s}, \mathrm{H}^{4^{\prime \prime}}\right), 7.01$ (2H, ddd, $J=7.5,6$ and $\left.1, \mathrm{H}^{4 "}\right), 6.99\left(1 \mathrm{H}, \mathrm{ddd}, J=6,2\right.$ and $\left.1, \mathrm{H}^{3}\right), 6.77$ $\left(1 \mathrm{H}, \mathrm{dd}, J=9\right.$ and $\left.3, \mathrm{H}^{5^{\prime}}\right), 6.47\left(1 \mathrm{H}\right.$, ddd, $J=7,6$ and $\left.1, \mathrm{H}^{4}\right)$, $6.39\left(1 \mathrm{H}, \mathrm{d}, J=9, \mathrm{H}^{6^{\prime}}\right), 4.11\left(3 \mathrm{H}, \mathrm{s}, \mathrm{H}^{\mathrm{NMe}}\right), 3.77\left(3 \mathrm{H}, \mathrm{s}, \mathrm{H}^{\mathrm{OMe}}\right)$, $2.88\left(6 \mathrm{H}, \mathrm{s}, \mathrm{H}^{\mathrm{Me}}\right) .{ }^{13} \mathrm{C} \mathrm{NMR}\left(\mathrm{CD}_{3} \mathrm{CN}, 176 \mathrm{MHz}\right): 179.6,170.6$, $157.3,156.0,151.4,151.3,150.7,140.6,139.7,139.5,139.0$, $138.7,125.0,123.8,123.4,122.4,119.3,117.5,116.4,110.1$, 56.5, 34.7, 22.5. MS (ES+): $m / z 708[\mathrm{M}]^{+}$; HRMS (ES+): $m / z$ $706.1912[\mathrm{M}]^{+}$; calculated for $\left[\mathrm{C}_{32} \mathrm{H}_{29} \mathrm{~N}_{5} \mathrm{O}_{2} \mathrm{Ir}\right]^{+} 706.1927$.

$\left[\operatorname{Ir}(\mathbf{d p y x}) \mathbf{H L}^{5}\right] \mathbf{P F}_{\mathbf{6}}$. A $2: 1$ mixture of $\mathrm{H}_{2} \mathrm{~L}^{5} \quad(36 \mathrm{mg}$, $0.096 \mathrm{mmol})$ and $[\operatorname{Ir}(\mathrm{dpyx}) \mathrm{Cl}(\mu-\mathrm{Cl})]_{2}(50 \mathrm{mg}, 0.048 \mathrm{mmol})$ in ethylene glycol $(1.5 \mathrm{~mL})$ was heated to $195{ }^{\circ} \mathrm{C}$ for 90 min under argon. Upon cooling to ambient temperature, water $(5 \mathrm{~mL})$ was added and the resulting orange-brown solid separated by filtration. The crude material was dissolved in the minimum volume of hot DMSO and the solution added dropwise into saturated aqueous $\mathrm{KPF}_{6}(5 \mathrm{~mL})$. The resulting yellow solid was separated by centrifugation and washed with water $(3 \times \mathrm{mL})$ to yield the product as a yellow solid (22 $\mathrm{mg}, 0.023 \mathrm{mmol}, 24 \%$ yield). ${ }^{1} \mathrm{H}$ NMR ( $\left.\mathrm{CD}_{3} \mathrm{CN}, 700 \mathrm{MHz}\right): 10.41(1 \mathrm{H}, \mathrm{s}), 8.90(1 \mathrm{H}, \mathrm{s})$, $8.25(2 \mathrm{H}, \mathrm{d}, J=9), 8.16(1 \mathrm{H}, \mathrm{s}), 7.85-7.82(4 \mathrm{H}, \mathrm{m}), 7.72(1 \mathrm{H}, \mathrm{dd}$, $J=8$ and 1.5), $7.51(1 \mathrm{H}, \mathrm{d}, J=8), 7.34(1 \mathrm{H}, \mathrm{t}, J=8), 7.18(1 \mathrm{H}, \mathrm{s})$, 7.11-7.06 (4H, m), 7.00-6.98 (2H, m), $6.69(1 \mathrm{H}, \mathrm{t}, J=7), 6.62$ $(1 \mathrm{H}, \mathrm{s}), 6.42(1 \mathrm{H}, \mathrm{d}, J=8), 4.10(3 \mathrm{H}, \mathrm{s}), 3.48(3 \mathrm{H}, \mathrm{s}), 2.91(6 \mathrm{H}$, s). ${ }^{13} \mathrm{C}$ NMR ( $\left.\mathrm{CD}_{3} \mathrm{CN}, 176 \mathrm{MHz}\right): 179.7,178.0,175.0,170.7$, 162.8 , 159.1, 158.1, 151.6, 141.1, 140.6, 139.8, 139.0, 136.2, $133.5,132.5,131.9,125.1,123.8,123.0,120.9,120.5,119.8$, 118.3, 117.4, 116.8, 85.1, 41.4, 33.9, 30.6, 22.5. MS (ES+): $\mathrm{m} / \mathrm{z}$ $827[\mathrm{M}+\mathrm{H}]^{+}$; HRMS (E+): $m / z$ 825.2443 [M] $]^{+}$; calculated for $\left[\mathrm{C}_{30} \mathrm{H}_{34} \mathrm{~N}_{8} \mathrm{O}_{2} \mathrm{Ir}\right]^{+}$825.2411.

$\left[\mathbf{I r}(\mathbf{d p y x}) \mathbf{H L}^{6}\right] \mathbf{P F}_{\mathbf{6}}$. This complex was prepared using a similar procedure to $\left[\operatorname{Ir}(\mathrm{dpyx}) \mathrm{HL}^{5}\right] \mathrm{PF}_{6}$ but starting from $\mathrm{H}_{2} \mathrm{~L}^{6}(90 \mathrm{mg}$, $0.184 \mathrm{mmol})$ and $\left[\operatorname{Ir}(\mathrm{dpyx}) \mathrm{Cl}(\mu-\mathrm{Cl}]_{2}(87 \mathrm{mg}, 0.084 \mathrm{mmol})\right.$. The final product was again a yellow solid $(64 \mathrm{mg}, 0.059 \mathrm{mmol}$, $32 \%$ yield). ${ }^{1} \mathrm{H}$ NMR ( $\left.\mathrm{CD}_{3} \mathrm{CN}, 700 \mathrm{MHz}\right): 10.29$ (1H, s), 8.92 $(1 \mathrm{H}, \mathrm{s}), 8.23(2 \mathrm{H}, \mathrm{d}, J=8), 8.14(1 \mathrm{H}, \mathrm{s}), 7.83-7.80(5 \mathrm{H}, \mathrm{m}), 7.71$ $(1 \mathrm{H}, \mathrm{d}, J=3), 7.50(1 \mathrm{H}, \mathrm{d}, J=2), 7.34(1 \mathrm{H}, \mathrm{dd}, J=8.5$ and 2$)$, 7.19 (1H, dd, $J=9$ and 2.5), $7.15(1 \mathrm{H}, \mathrm{s}), 7.07$ (2H, ddd, $J=7,6$ and 1), $7.03(1 \mathrm{H}, \mathrm{d}, J=0.5), 6.89(1 \mathrm{H}, \mathrm{d}, J=9), 6.58(1 \mathrm{H}, \mathrm{s})$, $6.36(1 \mathrm{H}, \mathrm{d}, J=9), 4.08(3 \mathrm{H}, \mathrm{s}), 3.45(3 \mathrm{H}, \mathrm{s}), 2.89(6 \mathrm{H}, \mathrm{s}), 1.30$ (9H, s), 1.29 (9H, s). ${ }^{13} \mathrm{C} \mathrm{NMR}\left(\mathrm{CD}_{3} \mathrm{CN}, 176 \mathrm{MHz}\right): 178.2,170.8$, $161.0,159.8,159.8,159.0,158.8,155.9,151.5,143.7,141.4$, $140.6,139.7,139.1,139.0,132.6,131.9,131.7,129.8,128.7$, 125.1, 123.8, 122.6, 119.3, 119.0, 118.3, 117.0, 85.0, 41.36, 34.7, 34.3, 33.9, 30.6, 22.5. MS (ES+): $m / z 940[\mathrm{M}+\mathrm{H}]^{+}$; HRMS (ES+): $m / z$ 937.3661 $[\mathrm{M}]^{+}$; calculated for $\left[\mathrm{C}_{46} \mathrm{H}_{50} \mathrm{~N}_{8} \mathrm{O}_{2} \mathrm{Ir}\right]^{+}$937.3663.

$\left[\mathbf{I r}(\mathbf{d p y F}) \mathbf{H L}^{\mathbf{6}}\right] \mathbf{P F}_{\mathbf{6}}$. This complex was obtained as a sideproduct in the synthesis of $\left[\left\{\operatorname{Ir}(\mathrm{dpyF})_{2}\right\} \mathrm{L}^{6}\right]\left(\mathrm{PF}_{6}\right)_{2}$ (see below) from which it was separated by column chromatography on silica and purified by recrystallisation from acetonitrile/diethyl ether (yellow solid, $9 \mathrm{mg}, 0.008 \mathrm{mmol}, 9 \%$ yield). ${ }^{1} \mathrm{H}$ NMR $\left(\mathrm{CD}_{3} \mathrm{CN}, 700 \mathrm{MHz}\right): \delta_{\mathrm{H}}=8.93\left(1 \mathrm{H}, \mathrm{s}, \mathrm{H}^{\mathrm{a}^{\prime}}\right), 8.23(2 \mathrm{H}, \mathrm{d}, J=8.2$, $\left.\mathrm{H}^{3^{\prime \prime}}\right), 8.19\left(1 \mathrm{H}, \mathrm{s}, \mathrm{H}^{\mathrm{a}}\right), 7.90\left(2 \mathrm{H}, \mathrm{td}, J=7.8,1.6, \mathrm{H}^{4^{\prime \prime}}\right), 7.83-7.77$ $\left(2 \mathrm{H}, \mathrm{m}, \mathrm{H}^{6^{\prime \prime}}\right), 7.72\left(1 \mathrm{H}, \mathrm{d}, J=2.7, \mathrm{H}^{5^{\prime}}\right), 7.54\left(1 \mathrm{H}, \mathrm{d}, J=2.5, \mathrm{H}^{\mathrm{e}}\right)$, $7.40\left(1 \mathrm{H}, \mathrm{dd}, J=8.7,2.5, \mathrm{H}^{\mathrm{d}}\right), 7.23-7.20\left(2 \mathrm{H}, \mathrm{m}, \mathrm{H}^{5^{\prime}}\right.$ and $\left.\mathrm{H}^{4^{\prime \prime \prime}}\right)$, 7.17-7.10 $\left(3 \mathrm{H}, \mathrm{m}, \mathrm{H}^{5^{\prime \prime}}\right.$ and $\left.\mathrm{H}^{6}\right), 6.93\left(1 \mathrm{H}, \mathrm{d}, J=8.6, \mathrm{H}^{\mathrm{b}}\right), 6.64$ $\left(1 \mathrm{H}, \mathrm{s}, \mathrm{H}^{3}\right), 6.41\left(1 \mathrm{H}, \mathrm{d}, J=8.9, \mathrm{H}^{3^{\prime}}\right), 4.11\left(3 \mathrm{H}, \mathrm{s}, \mathrm{H}^{\mathrm{b}^{\prime}}, \mathrm{NMe}\right)$, $3.50\left(3 \mathrm{H}, \mathrm{s}, \mathrm{H}^{\mathrm{b}^{\prime \prime}}, \mathrm{NMe}\right), 1.32\left(9 \mathrm{H}, \mathrm{s}, \mathrm{H}^{7^{\prime}},{ }^{t} \mathrm{Bu}\right), 1.31\left(9 \mathrm{H}, \mathrm{s}, \mathrm{H}^{\mathrm{f}}\right.$, $\left.{ }^{t} \mathrm{Bu}\right) .{ }^{19} \mathrm{~F} \mathrm{NMR}\left(\mathrm{CD}_{3} \mathrm{CN}, 376 \mathrm{MHz}\right): \delta_{\mathrm{F}}=-107.86(4 \mathrm{~F}, \mathrm{~d}, J=12)$, -72.94 (12F, d, $J=710, \mathrm{PF}_{6}{ }^{-}$). HRMS (ES+): $m / z$ 945.3131 [M] $]^{+}$; calculated for $\left[\mathrm{C}_{44} \mathrm{H}_{44} \mathrm{~N}_{8} \mathrm{O}_{2} \mathrm{~F}_{2} \mathrm{Ir}\right]^{+}$945.3161.

$\left[\{\operatorname{Ir}(\mathbf{d p y x})\}_{2} \mathbf{L}^{5}\right]\left(\mathbf{P F}_{\mathbf{6}}\right)_{2}$. A $1: 1$ mixture of $\mathrm{H}_{2} \mathrm{~L}^{5}(22 \mathrm{mg}$, $0.058 \mathrm{mmol})$ and $\left[\operatorname{Ir}(\mathrm{dpyx}) \mathrm{Cl}(\mu-\mathrm{Cl}]_{2}(61 \mathrm{mg}, 0.058 \mathrm{mmol})\right.$ was heated to $195{ }^{\circ} \mathrm{C}$ in ethylene glycol $(1.5 \mathrm{~mL})$ for 90 min under argon. Upon cooling to ambient temperature, water $(2 \mathrm{~mL})$ was added. The precipitated material was dissolved in the minimum volume of hot DMSO, and added dropwise into saturated aqueous $\mathrm{KPF}_{6}$ solution $(5 \mathrm{~mL})$. The resulting precipitate was collected by centrifugation, washed with water $(3 \times$ $\mathrm{mL}$ ), and recystallised from $\mathrm{MeCN} / \mathrm{Et}_{2} \mathrm{O}$ to yield the desired product as a yellow solid (4 $\mathrm{mg}, 0.003 \mathrm{mmol}, 5 \%$ yield). ${ }^{1} \mathrm{H}$ NMR ( $\left.\mathrm{CD}_{3} \mathrm{CN}, 700 \mathrm{MHz}\right): 8.83\left(2 \mathrm{H}, \mathrm{s}, \mathrm{H}^{\text {imine }}\right), 8.01(4 \mathrm{H}, \mathrm{d}$, $\left.J=8, \mathrm{H}^{3^{\prime \prime}}\right), 7.70\left(4 \mathrm{H}\right.$, ddd, $J=8,7.5$ and $\left.1.5, \mathrm{H}^{4^{\prime \prime}}\right), 7.64(2 \mathrm{H}, \mathrm{dd}$, $J=8$ and $\left.2, \mathrm{H}^{3^{\prime}}\right), 7.53\left(4 \mathrm{H}, \mathrm{dd}, J=6\right.$ and $\left.1, \mathrm{H}^{6^{\prime \prime}}\right), 7.15\left(2 \mathrm{H}, \mathrm{s}, \mathrm{H}^{4^{\prime \prime}}\right.$ '), $7.04\left(2 \mathrm{H}\right.$, ddd, $J=9,7$ and $\left.2, \mathrm{H}^{5^{\prime}}\right), 6.87$ (4H, ddd, $J=7.5,5.5$ and 1), $6.63(2 \mathrm{H}$, ddd, $J=8,7$ and 1$), 6.46\left(1 \mathrm{H}, \mathrm{s}, \mathrm{H}^{6}\right), 6.28(2 \mathrm{H}$, $\left.\mathrm{d}, J=9, \mathrm{H}^{6^{\prime}}\right), 5.97\left(1 \mathrm{H}, \mathrm{s}, \mathrm{H}^{3}\right), 4.10\left(6 \mathrm{H}, \mathrm{s}, \mathrm{H}^{\mathrm{NMe}}\right), 2.88(12 \mathrm{H}, \mathrm{s}$, $\left.\mathrm{H}^{\mathrm{Me}}\right) .{ }^{13} \mathrm{C}$ NMR ( $\left.\mathrm{CD}_{3} \mathrm{CN}, 176 \mathrm{MHz}\right): 175.7\left(\mathrm{C}^{1^{\prime \prime \prime}}\right), 170.0\left(\mathrm{C}^{2 "}\right)$, $163.0\left(\mathrm{C}^{1^{\prime}}\right), 162.1\left(\mathrm{C}^{2^{\prime \prime \prime}}\right), 156.2\left(\mathrm{C}^{2}\right), 151.6\left(\mathrm{C}^{6^{\prime \prime}}\right), 142.4\left(\mathrm{C}^{\text {imine }}\right)$, $140.6\left(C^{4^{\prime \prime}}\right), 139.0\left(C^{3^{\prime \prime \prime}}\right), 138.50\left(C^{2^{\prime \prime \prime}}\right), 136.3\left(C^{3^{\prime}}\right), 134.0\left(C^{5^{\prime}}\right)$, $133.5\left(\mathrm{C}^{4^{\prime \prime \prime}}\right), 124.5\left(\mathrm{C}^{3^{\prime \prime}}\right), 123.5\left(\mathrm{C}^{5^{\prime \prime}}\right), 122.9\left(\mathrm{C}^{6^{\prime}}\right), 119.9\left(\mathrm{C}^{2^{\prime}}\right)$, $117.1\left(\mathrm{C}^{4^{\prime}}\right), 84.65\left(\mathrm{C}^{6}\right), 34.70\left(\mathrm{C}^{\mathrm{NMe}}\right), 23.0\left(\mathrm{C}^{\mathrm{Me}}\right) . \mathrm{MS}(\mathrm{ES}+): \mathrm{m} / \mathrm{z}$ $639[\mathrm{M}]^{2+}$.

$\left[\{\operatorname{Ir}(\mathbf{d p y x})\}_{2} \mathbf{L}^{6}\right]\left(\mathbf{P F}_{\mathbf{6}}\right)_{2}$. This complex was obtained using a similar procedure to $\left[\{\operatorname{Ir}(\mathrm{dpyx})\}_{2} \mathrm{~L}^{5}\right]\left(\mathrm{PF}_{6}\right)_{2}$ but starting from a $1: 1$ mixture of $\mathrm{H}_{2} \mathrm{~L}^{6}(24 \mathrm{mg}, 0.048 \mathrm{mmol})$ and $[\operatorname{Ir}(\mathrm{dpyx}) \mathrm{Cl}(\mu-$ $\mathrm{Cl}_{2}$ (50 mg, $0.048 \mathrm{mmol}$ ). The crude material was purified by column chromatography (5\% $\mathrm{MeOH}$ in DCM), followed by recrystallisation from $\mathrm{MeCN} / \mathrm{Et}_{2} \mathrm{O}$, to yield the final product as a yellow solid (8 mg, $0.006 \mathrm{mmol}, 12 \%$ yield). ${ }^{1} \mathrm{H}$ NMR $\left(\mathrm{CD}_{3} \mathrm{CN}, 700 \mathrm{MHz}\right): 8.87\left(2 \mathrm{H}, \mathrm{s}, \mathrm{H}^{\text {imine }}\right), 8.02\left(4 \mathrm{H}, \mathrm{d}, J=8, \mathrm{H}^{3 \prime}\right)$, $7.71\left(4 \mathrm{H}\right.$, ddd, $J=8,7.5$ and $\left.1.5, \mathrm{H}^{4^{\prime \prime}}\right), 7.64\left(2 \mathrm{H}, \mathrm{d}, J=2.5, \mathrm{H}^{3^{\prime}}\right)$, $7.53\left(4 \mathrm{H}\right.$, ddd, $J=6,2$ and $\left.0.5, \mathrm{H}^{6 \prime}\right), 7.16-7.14\left(4 \mathrm{H}, \mathrm{m}, \mathrm{H}^{5^{\prime}}\right.$ and $\left.\mathrm{H}^{4^{\prime \prime \prime}}\right), 6.89\left(4 \mathrm{H}\right.$, ddd, $J=7,6$ and $\left.1, \mathrm{H}^{5 \prime}\right), 6.45\left(1 \mathrm{H}, \mathrm{s}, \mathrm{H}^{6}\right), 6.25$ $\left(2 \mathrm{H}, \mathrm{d}, J=9, \mathrm{H}^{6^{\prime}}\right), 5.97\left(1 \mathrm{H}, \mathrm{s}, \mathrm{H}^{3}\right), 4.12\left(6 \mathrm{H}, \mathrm{s}, \mathrm{H}^{\mathrm{NMe}}\right), 2.89$ $\left(12 \mathrm{H}, \mathrm{s}, \mathrm{H}^{\mathrm{Me}}\right), 1.26\left(18 \mathrm{H}, \mathrm{s}, \mathrm{H}^{\mathrm{butyl}}\right) \cdot{ }^{13} \mathrm{C} \mathrm{NMR}\left(\mathrm{CD}_{3} \mathrm{CN}\right.$, $176 \mathrm{MHz}): 175.9\left(\mathrm{C}^{1^{\prime \prime}}\right), 170.0\left(\mathrm{C}^{2^{\prime \prime \prime}}\right), 162.1\left(\mathrm{C}^{3}\right), 161.2\left(\mathrm{C}^{1^{\prime}}\right), 156.0$ $\left(C^{2}\right), 151.5\left(C^{6^{\prime \prime}}\right), 142.7\left(C^{\text {imine }}\right), 140.6\left(C^{4^{\prime \prime}}\right), 139.5\left(C^{4^{\prime}}\right), 139.0$ $\left(\mathrm{C}^{3^{\prime \prime \prime}}\right), 138.5\left(\mathrm{C}^{2^{\prime \prime}}\right), 133.4\left(\mathrm{C}^{5^{\prime}}\right.$ or $\left.\mathrm{C}^{4^{\prime \prime \prime}}\right), 132.2\left(\mathrm{C}^{5^{\prime}}\right.$ or $\left.\mathrm{C}^{4^{\prime \prime \prime}}\right), 131.9$ $\left(\mathrm{C}^{3^{\prime}}\right), 124.5\left(\mathrm{C}^{3^{\prime \prime}}\right), 123.5\left(\mathrm{C}^{5^{\prime \prime}}\right), 122.4\left(\mathrm{C}^{6^{\prime}}\right), 118.9\left(\mathrm{C}^{2^{\prime}}\right), 84.5\left(\mathrm{C}^{6}\right)$, $34.7\left(\mathrm{C}^{\mathrm{NMe}}\right), 34.3\left(\mathrm{C}^{7^{\prime}}\right), 31.6\left(\mathrm{C}^{\text {butyl }}\right), 23.0\left(\mathrm{C}^{\mathrm{Me}}\right)$. MS (ES+): $\mathrm{m} / \mathrm{z}$ $695[\mathrm{M}]^{2+} ; \operatorname{HRMS}(\mathrm{ES}+): \mathrm{m} / \mathrm{z} 694.2226[\mathrm{M}]^{2+}$; calculated for $\left[\mathrm{C}_{64} \mathrm{H}_{62} \mathrm{~N}_{10} \mathrm{O}_{2} \mathrm{Ir}_{2}\right]^{2+} 694.2188$.

$\left[\{\mathbf{I r}(\mathbf{d p y} \mathbf{F})\}_{2} \mathbf{L}^{\mathbf{6}}\right]\left(\mathbf{P F}_{\mathbf{6}}\right)_{2}$. This complex was obtained using a similar procedure to $\left[\{\operatorname{Ir}(\mathrm{dpyx})\}_{2} \mathrm{~L}^{5}\right]\left(\mathrm{PF}_{6}\right)_{2}$ but starting from a $1: 1$ mixture of $\mathrm{H}_{2} \mathrm{~L}^{6}(46 \mathrm{mg}, 0.094 \mathrm{mmol})$ and $[\operatorname{Ir}(\mathrm{dpyF}) \mathrm{Cl}(\mu$ $\mathrm{Cl})]_{2}$ (100 mg, $0.094 \mathrm{mmol}$ ). The crude material was purified by column chromatography ( $2 \% \mathrm{MeOH}$ in DCM), followed by recrystallisation from $\mathrm{MeCN} / \mathrm{Et}_{2} \mathrm{O}$, to yield the final product as a yellow solid (18 mg, $0.013 \mathrm{mmol}, 12 \%$ yield). ${ }^{1} \mathrm{H}$ NMR 
$\left(\mathrm{CD}_{3} \mathrm{CN}, 600 \mathrm{MHz}\right) \delta 8.90\left(2 \mathrm{H}, \mathrm{s}, \mathrm{H}^{\text {imine }}\right), 8.09(4 \mathrm{H}, \mathrm{d}, J=8.2$, $\left.\mathrm{H}^{3^{\prime \prime}}\right), 7.88-7.73\left(4 \mathrm{H}, \mathrm{m}, \mathrm{H}^{4^{\prime \prime}}\right), 7.67\left(2 \mathrm{H}, \mathrm{d}, J=2.2, \mathrm{H}^{3^{\prime}}\right), 7.54(4 \mathrm{H}$, $\left.\mathrm{d}, J=5.7, \mathrm{H}^{6^{\prime \prime}}\right), 7.24\left(2 \mathrm{H}, \mathrm{t}, J=10.2, \mathrm{H}^{4^{\prime \prime \prime}}\right), 7.19(2 \mathrm{H}, \mathrm{dt}, J=9.0$, 2.0, $\left.\mathrm{H}^{5^{\prime}}\right), 6.97\left(4 \mathrm{H}, \mathrm{td}, J=6.6,5.7,1.5, \mathrm{H}^{5^{\prime \prime}}\right), 6.48\left(1 \mathrm{H}, \mathrm{s}, \mathrm{H}^{6}\right)$, $6.33\left(2 \mathrm{H}, \mathrm{dd}, J=9.1,1.4, \mathrm{H}^{6^{\prime}}\right), 5.91\left(1 \mathrm{H}, \mathrm{s}, \mathrm{H}^{3}\right), 4.13(6 \mathrm{H}, \mathrm{s}$, $\left.\mathrm{H}^{\mathrm{Me}}\right), 1.26\left(18 \mathrm{H}, \mathrm{s}, \mathrm{H}^{\text {butyl }}\right) .{ }^{19} \mathrm{~F} \mathrm{NMR}\left(\mathrm{CD}_{3} \mathrm{CN}, 376 \mathrm{MHz}\right) \delta_{\mathrm{F}}=$ -107.1 (4F, d, $J=14$ ), -72.9 (12F, d, $J=710, \mathrm{PF}_{6}{ }^{-}$). HRMS (ES+): $m / z 703.1696[\mathrm{M}]^{2+}$; calculated for $\left[\mathrm{C}_{60} \mathrm{H}_{50} \mathrm{~F}_{4} \mathrm{Ir}_{2} \mathrm{~N}_{10} \mathrm{O}_{2}\right]^{2+}$ 703.1740 .

\section{Conflicts of interest}

There are no conflicts of interests to declare.

\section{Acknowledgements}

We thank EPSRC and Durham University for support.

\section{Notes and references}

1 (a) Highly Efficient OLEDs with Phosphorescent Materials, ed. H. Yersin, Wiley-VCH, Weinheim, 2007; (b) C. Cebrian and M. Mauro, Beilstein J. Org. Chem., 2018, 14, 1459; (c) J. Kalinwoski, V. Fattori, M. Cocchi and J. A. G. Williams, Coord. Chem. Rev., 2009, 253, 1709; (d) P. T. Chou, Y. Chi, M. W. Chung and C. C. Lin, Coord. Chem. Rev., 2011, 255, 2653.

2 (a) R. D. Costa, E. Ortí, H. J. Bolink, F. Monti, G. Accorsi and N. Armaroli, Angew. Chem., Int. Ed., 2012, 51, 8178; (b) S. Ladouceur and E. Zysman-Colman, Eur. J. Inorg. Chem., 2013, 2985; (c) B. Pashaei, S. Karmi, H. Shahroosvand and M. Pilkington, Adv. Funct. Mater., 2020, 1908103; (d) Q. Y. Zheng, F. Li, Z. Y. Chen, K. Yang, Y. Liu, T. L. Guo, G. G. Shan and Z. M. Su, ACS Appl. Mater. Interfaces, 2020, 12, 4649.

3 (a) A. Genoni, D. N. Chirdon, M. Boniolo, A. Sartorel, S. Bernhard and M. Bonchio, ACS Catal., 2017, 7, 154; (b) I. N. Mills, J. A. Porras and S. Bernhard, Acc. Chem. Res., 2018, 51, 352; (c) R. Matheu, P. Garrido-Barros, M. GilSepulcre, M. Z. Ertem, X. Sala, C. Gimbert-Surinach and A. Llobet, Nat. Rev. Chem., 2019, 3, 331.

4 (a) A. Trowbridge, D. Reich and M. J. Gaunt, Nature, 2018, 561, 522; (b) J. Zhang, W. B. Swords, H. Jung, K. L. Skubi, J. B. Kidd, G. J. Meyer, M. H. Baik and T. P. Yoon, J. Am. Chem. Soc., 2019, 141, 13625; (c) P. S. Kim, S. Choi, S. Y. Kim, J. H. Jo, Y. S. Lee, B. Kim, W. Kim, W. Choi, C. H. Kim, H. J. Son, C. Pac and S. O. Kang, Chem. - Eur. J., 2019, 25, 13609; (d) M. Yang, J. E. Yarnell, K. El Roz and F. N. Castellano, ACS Appl. Energy Mater., 2020, 3, 1842.

5 (a) K. K. W. Lo, A. W. T. Choi and W. H. T. Law, Dalton Trans., 2012, 41, 6021; (b) E. Baggaley, J. A. Weinstein and J. A. G. Williams, Coord. Chem. Rev., 2012, 256, 1762; (c) M. Mauro, A. Aliprandi, D. Septiadi, N. S. Kehr and
L. De Cola, Chem. Soc. Rev., 2014, 43, 4144; (d) Y. Chen, R. Guan, C. Zhang, J. Huang, L. Ji and H. Chao, Coord. Chem. Rev., 2016, 310, 16; (e) A. M. H. Yip and K. K. W. Lo, Coord. Chem. Rev., 2018, 361, 138; $(f)$ A. M. Ranieri, C. Caporale, V. Fiorini, A. Hubbard, P. Rigby, S. Stagni, W. Watkin, M. I. Ogden, M. J. Hackett and M. Massi, Chem. - Eur. J., 2019, 25, 10566.

$6 \mathrm{~J}$. A. G. Williams, Multinuclear iridium complexes in Iridium(III) in Optoelectronic and Photonics Applications, ed. E. Zysman-Colman, Wiley, Chichester, 2017.

7 (a) G. Li, D. G. Congrave, D. Zhu, Z. Su and M. R. Bryce, Polyhedron, 2018, 140, 146; (b) G. Li, D. Zhu, X. Wang, Z. Su and M. R. Bryce, Chem. Soc. Rev., 2020, 49, 765.

8 (a) S. Welter, F. Lafolet, E. Cecchetto, F. Verrgeer and L. De Cola, ChemPhysChem, 2005, 6, 2417; (b) S. Welter, N. Salluce, A. Benetti, N. Rot, P. Belser, P. Sonar, A. C. Grimsdale, K. Müllen, M. Lutz, A. L. Spek and L. De Cola, Inorg. Chem., 2005, 44, 4706; (c) M. Cavazzini, S. Quici, C. Scalera, F. Puntoriero, G. La Ganga and S. Campagna, Inorg. Chem., 2009, 48, 8578.

9 (a) K. J. Arm and J. A. G. Williams, Chem. Commun., 2005, 230; (b) K. J. Arm and J. A. G. Williams, Dalton Trans., 2006, 2172; (c) W. Leslie, A. S. Batsanov, J. A. K. Howard and J. A. G. Williams, Dalton Trans., 2004, 623; (d) C. Sabatini, A. Barbieri, F. Barigelletti, K. J. Arm and J. A. G. Williams, Photochem. Photobiol. Sci., 2007, 6, 397; (e) K. J. Knuckey and J. A. G. Williams, Eur. J. Inorg. Chem., 2017, 5205.

10 (a) V. L. Whittle and J. A. G. Williams, Inorg. Chem., 2008, 47, 6596; (b) V. L. Whittle and J. A. G. Williams, Dalton Trans., 2009, 3929.

11 (a) P. H. Lanoë, C. M. Tong, R. W. Harrington, M. R. Probert, W. Clegg, J. A. G. Williams and V. N. Kozhevnikov, Chem. Commun., 2014, 50, 6381; (b) R. E. Daniels, S. Culham, M. Hunter, M. C. Durrant, M. R. Probert, W. Clegg, J. A. G. Williams and V. N. Kozhevnikov, Dalton Trans., 2016, 45, 6949.

12 (a) S. Culham, P. H. Lanoë, V. L. Whittle, M. C. Durrant, J. A. G. Williams and V. N. Kozhevnikov, Inorg. Chem., 2013, 52, 10992; (b) M. Z. Shafikov, R. Daniels, P. Pander, F. B. Dias, J. A. G. Williams and V. N. Kozhevnikov, ACS Appl. Mater. Interfaces, 2019, 11, 8182.

13 E. V. Puttock, M. T. Walden and J. A. G. Williams, Coord. Chem. Rev., 2018, 367, 127.

14 (a) V. N. Kozhevnikov, M. C. Durrant and J. A. G. Williams, Inorg. Chem., 2011, 50, 6304; (b) G. Turnbull, J. A. G. Williams and V. N. Kozhevnikov, Chem. Commun., 2017, 53, 2729.

15 J. P. Sauvage, J. P. Collin, J. C. Chambron, S. Guillerez, C. Coudret, V. Balzani, F. Barigelletti, L. De Cola and L. Flamigni, Chem. Rev., 1994, 94, 993.

16 (a) A. J. Wilkinson, A. E. Goeta, C. E. Foster and J. A. G. Williams, Inorg. Chem., 2004, 43, 6513; (b) A. J. Wilkinson, A. E. Goeta, C. E. Foster and J. A. G. Williams, Inorg. Chem., 2006, 45, 8685; (c) P. Brulatti, R. J. Gildea, J. A. K. Howard, V. Fattori, M. Cocchi and J. A. G. Williams, Inorg. Chem., 2012, 51, 
3813; (d) L. F. Gildea, A. S. Batsanov and J. A. G. Williams, Dalton Trans., 2013, 42, 10388.

17 (a) J. A. G. Williams, A. J. Wilkinson and V. L. Whittle, Dalton Trans., 2008, 2081; (b) J. A. G. Williams, Chem. Soc. Rev., 2009, 38, 1783.

18 (a) S. Obara, M. Itabishi, F. Okuda, S. Tamaki, Y. Tanabe, Y. Ishii, K. Nozaki and M.-A. Haga, Inorg. Chem., 2006, 45, 8907; (b) M. Ashikawa, L. Yang, K. Kobayashi, H. Sato, A. Yamagishi, F. Okuda, T. Harada, R. Kuroda and M.-A. Haga, Dalton Trans., 2009, 1700; (c) J. Kuwabara, T. Namekawa, M.-A. Haga and T. Kanbara, Dalton Trans., 2012, 21.

19 (a) B. Tong, H. Y. Ku, I. J. Chen, Y. Chi, H. C. Kao, C. C. Yeh, C. H. Chang, S. H. Liu, G. H. Lee and P. T. Chou, J. Mater. Chem. C, 2015, 3, 3460; (b) Y. Chi, T. K. Chang, P. Ganesan and P. Rajakannu, Coord. Chem. Rev., 2017, 346, 91.

20 (a) C. Y. Kuei, W. L. Tsai, B. Tong, M. Jiao, W. K. Lee, Y. Chi, C. C. Wu, S. H. Liu, G. H. Lee and P. T. Chou, Adv. Mater., 2016, 28, 2795; (b) J. L. Liao, P. Rajakannu, P. Gnanasekaran, S. R. Tsai, C. H. Lin, S. H. Liu, C. H. Chang, G. H. Lee, P. T. Chou, Z. N. Chen and Y. Chi, Adv. Opt. Mater., 2018, 6, 1800083; (c) L. Y. Hsu, D. G. Chen, S. H. Liu, T. Y. Chiu, C. H. Chang, A. K. Y. Jen, P. T. Chou and Y. Chi, ACS Appl. Mater. Interfaces, 2020, 12, 1084.

21 E. V. Puttock, J. D. Fradgley, D. S. Yufit and J. A. G. Williams, Dalton Trans., 2019, 48, 15012.

22 Similar ligands in combination with $\mathrm{Fe}(\mathrm{III})$ have been shown to form tetranuclear grids in which the pyrimidine rings bridge two metal ions: Y.-T. Wang, A.-L. Cui, D.-Z. Shen and H.-Z. Kou, Polyhedron, 2013, 52, 970.

23 (a) A. Sarkar and S. Pal, Polyhedron, 2006, 25, 1689; (b) D. Ramakrishna and B. R. Bhat, Inorg. Chem. Commun., 2010, 13, 195; (c) W. Cao, Y. Liu, T. Zhang and J. Jia, Polyhedron, 2018, 147, 62.

24 J. L. Schmitt, A. M. Stadler, N. Kyritsakas and J. M. Lehn, Helv. Chim. Acta, 2003, 86, 1598.

25 K. L. Garner, L. F. Parkes, J. D. Piper and J. A. G. Williams, Inorg. Chem., 2010, 49, 476.

26 J. P. Collin, I. M. Dixon, J. P. Sauvage, J. A. G. Williams, F. Barigelletti and L. Flamigni, J. Am. Chem. Soc., 1999, 121, 5009.

27 D. L. Rochester, S. Develay, S. Záliš and J. A. G. Williams, Dalton Trans., 2009, 1728.

28 H. Yersin, A. F. Rausch, R. Czerwieniec, T. Hofbeck and T. Fischer, Coord. Chem. Rev., 2011, 255, 2622.

29 (a) E. I. Solomon, Comments Inorg. Chem., 1984, 3, 225; (b) H. Yersin and D. Donges, Top. Curr. Chem., 2001, 214, 81; (c) A. F. Rausch, L. Murphy, J. A. G. Williams and H. Yersin, Inorg. Chem., 2012, 51, 312.

30 M. Z. Shafikov, R. Daniels and V. N. Kozhevnikov, J. Phys. Chem. Lett., 2019, 10, 7015.

31 O. V. Dolomanov, L. J. Bourhis, R. J. Gildea, J. A. K. Howard and H. Puschmann, J. Appl. Crystallogr., 2009, 42, 339-341.

32 G. M. Sheldrick, Acta Crystallogr., Sect. A: Found. Crystallogr., 2008, 64, 112-122.

33 K. Suzuki, A. Kobayashi, S. Kaneko, K. Takehira, T. Yoshihara, H. Ishida, Y. Shiina, S. Oishi and S. Tobita, Phys. Chem. Chem. Phys., 2009, 11, 9850. 